UC-NRLF

U. S. DEPARTMENT OF AGRICULTURE DIVISION OF VEGETABLE PATHOLOGY

EXPERIMENTS IN PREVENTING

LEAF DISEASES OF NURSERY STOCK IN WESTERN NEW YORK BY

D. G. FAIROHLD 

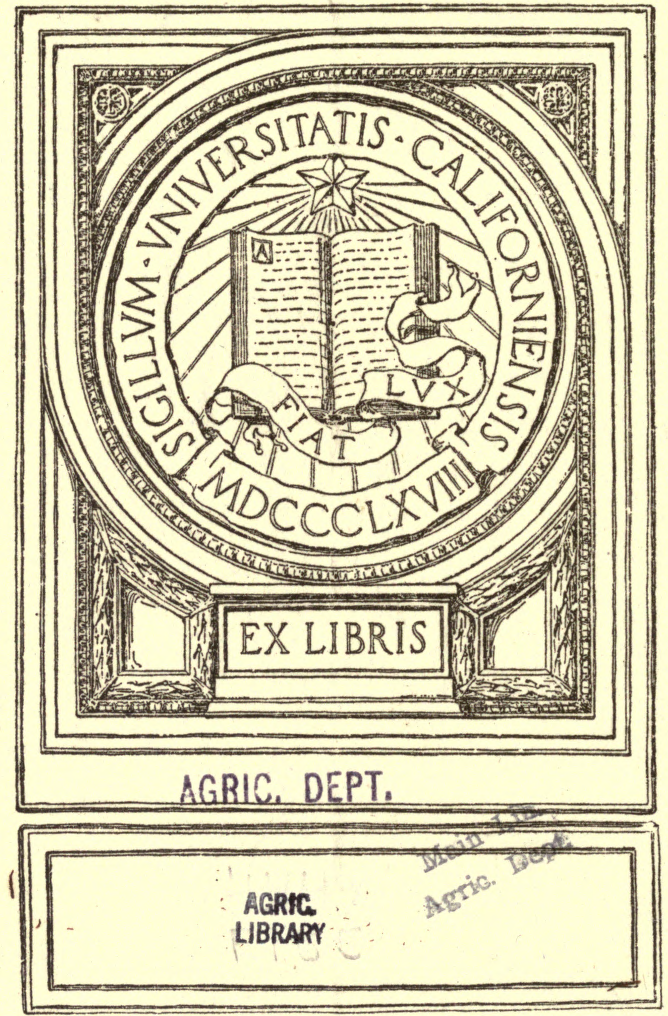






\section{AGRICULTURAL LIBRARY, ONIVERSITY$$
\rightarrow \text { OF- }
$$ \\ CALIFORNIA.}

U. S. DEPARTMENT OF AGRICULTURE.

- DIVISION OF VEGETABLE PATHOLOGY.

EXPERIMENTS IN PREVENTING LEAF DISEASES OF NURSERY STOCK IN WESTERN NEW YORK.

BY D. G. FAIRCHILD.

REPRINTED FizoN tile JOURNAI, OF MYCology, VOL. 7 , No. 3 , BY aUthority OF THK SECRETARY UF AGRCULTURE.

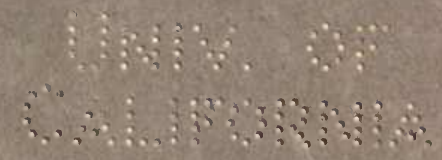




\section{U. S. DEPAR'TMENT OF, AGRICULTURE.}

DIVISION OF VEGETABLE PATHOLOGY.

EXPERINENTS IN PREVENTING LEAF DISEASES OF NURSERY STOCK IN WESTERN NEW YORK.

$$
\text { BY D. G. FA IRCHILD. }
$$

Reprinted From the Journat, of MYCOlogy, Vol. 7, No. 3, BY aUthority OF THE SECRetary of Agriculture.

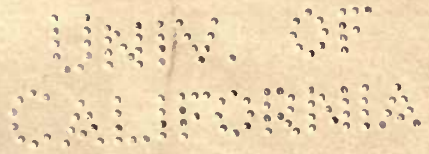




\title{
EXPERIMENTS IN PREVENTING LEAF DISEASES OF NURSERY STOCK IN WESTERN NEW YORK.
}

\author{
By D. G. FAIRCHILD.
}

\section{[Plates XXI-XXIX.]}

It is the intention to give in the following paper a brief account of experiments made during the seasons of 1891 and 1892 with a view of preventing the various leaf diseases of nursery stock. These experiments were carried on at Geneva, N. Y., one of the largest nursery centers east of the Mississippi. The kindness of Dr. Collier, director of the New York State Agricultural Experiment Station, made it possible for the work to be done upon the station grounds, where proximity to the laboratories and assistance from the station staft greatly facilitated the work.

To bring together in one article the results of the experiments, it will be necessary to repeat in part matter that has previously been published.*

The original object of the experiments conducted at Geneva was to throw light upon the following questions:

(1) Can the leaf-blight of pear, cherry, plum, and quince stocks and the powdery mildew of the apple be prevented by the use of Bordeanx mixture or ammoniacal solution of copper carbonate?

(2) What effect is produced upon the growth of nursery stock, budded and not budded, by repeated treatments with Bordeaux mixture and ammoniacal solution?

(3) What effect, if any, has the variety of stock upon the scion or "bud" with respect to its resistance to leaf-blight?

While the experiments have thrown considerable light upon the first and second questions, the nursery was not extensive enough nor the soil uniform $t$ enough to admit of any but general conclusious being drawn as to the third question. Further, the experiment was begun so late in the season that it was not possible to secure stocks of uniform size, and it is doubtful if any experiments, unless made upon uniform soil, with stocks grown from cuttings, will settle in a satisfactory manner a phase of this problem in which there are so many variable factors.

The various leaf diseases will now be diseussed, together with the results of the experiments made for preventing them. The numerous

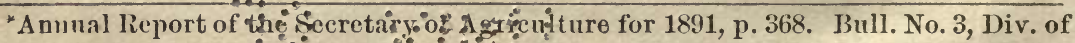
Veg. Pathology, pp. 57-60. 'renth Anv. -lieport N. Y. Agrl. Expt. Sta., 1892, pp. 179-181.

$$
\therefore \vdots \because \because \because \because \cdots: \therefore \cdots
$$

† As the experinents qrogressed it vo placinly ovident that a strip 30 feet or so wide, at the west end of the block, had at some previous time received fertilizers, which renilered it eminently suited to the needs of pear stocks. As no accurato record of this portion of the farm seems to have becu kept, it was impossible to ascertain what fortilizers had been used upon the strip. 
details, of interest only to those who are pursuing similar studies, are given in small type at the close of the article.

\section{PEAR LEAF-BLIGH'T (Entomosporium maculatum Lév.).}

This disease is perhaps the greatest obstacle to the profitable pro. duction of pear stocks. The principal injury is caused by a premature defoliation of the seedlings. When such defoliation takes place early in the season, as is quite commonly the case, the young seedlings are forced to form a new set of leaves, presumably at great expense to the reserve material stored for use the coming spring. Often this formation of new leaves is repeated two or three times, the seedling finally becoming too exhausted to continue the struggle. If the following winter be survived, enough growth may be made to render budding possible.

Although the disease is very abundant on bearing trees further south, it seems to be confined in western New York, at least in its severe attacks, to one, two, and three year old seedlings, occasionally defoliating a budded stock of some susceptible variety like the Flemish Beauty. All ordinary budded stocks are commonly immune from the disease, although the stocks into which the buds are inserted may have been diseased before being budded.* So far as the author's observations go the fungus eausing the disease does not attack the seeds of the pear or the cotyledons of the young seedlings until two weeks after the appearanee of the latter above the surface of the soil. Early in the season it attacks only the foliage, but later, as the defoliation continues, it is found on the succulent growing tip of the stem. For 3 or 4 inches from the terminal bud the bark is covered with small, sunken spots, bearing in their centers the mature fruiting bodies of the fungus, this condition first becoming noticeable about the middle of Angust. As first pointed out by Sorauer, $\uparrow$ it is in these sunken spots that the parasite passes the winter. In America the parasite lives from year to year, as it does in Germany, upon the bark of the growing seedling and infects the young leaves upon their first appearance in the spring. On May 20, before the foliage of last season's unbudded stocks was two-thirds grown, mature pustules were found upon the young leaves in immediate proximity to these spots upon the twigs. A microscopic examination of the spots revealed the parasite in an active condition. There is little doubt that the infected twigs

\footnotetext{
*'The terms "seedlings" and "stocks" are here employed as in common use among nurserymen. A seedling in nursery parlance means a plant grown from seed before it is transplanted into the nursery row, while the term stock is used to designate the scedling after transplanting either before or after bulding. Whenever I have referred to stocks which havo been budled I havo used the terms "budded stocks" or "buls."

†Sorauer, P. Haudl). d. Pflanzenkranklieiten. Zweite Aңી., 1886, vol. II, p. 373. Monatschr. d. Ver, zur Beförd. d. Garteub. Kgl. preuss. St., Jan. 1878. (Cited by Frank, Krankh. d. Pfl., 1880, p. 590.)
} 
are the principal means by which the fungus is carried through the winter and the presence of an ascigerous form, deseribed by Soraner, seems almost unnecessary to a maintenance of the disease in a region once infested.

The practice of allowing stocks to remain in the nursery rows when leaf-blight has affected them so severely as to render them unbudable, seens unwise when considered from a hygienic standpoint. Such stoeks are almost sure to harbor the parasite in its winter form upon their slender branches, which are lacking in vigor. It is from these stocks that the disease apparently spreads to other plantings of seedlings in the vicinity and to such budded stocks as are susceptible. It would seem advisable, therefore, that when leaf-blight causes a large number of failures in the seed bed, the diseased seedlings shonld be headed back to within 1 or 2 inches of the ground and all side shoots likely to harbor the parasite removed. Such procedure would undoubtedly decrease the liability to so early an attack of the disease and enable growth to be made before the malady had time to spread from infected loealities. The same immunity as that shown by rapidly growing "buds" may prove here a valuable factor. It has been objected, however, that the simultaneous appearance of several shoots from the headed back seedling would prevent, or at least materially linder the budders in their work the following fall. This obstacle eould be overcome by the early removal of all but one shoot. It seems to me that this method of eradicating the disease is sufficiently promising to warrant a thorough test. The matter of protecting seedlings by wind-breaks has not been thoroughly tested to my knowledge, and from observation on the spread of the disease I am inclined to believe it is worthy a systematic trial. The freedom from leaf-blight, which isolated blocks of pear seedlings often show, tends to confirm the ob. servation that the malady travels quite slowly from seedling to seedling. In an experimental block of seedlings mentioned below it required nearly two months for the disease to travel from the east to the west end, a distance of 150 feet.

Two quite distinet experiments were made with a view of preventing this disease, one inaugurated in 1891 to test the effect of fungicides upon stocks, and the other carried on during the season of 1892 with seedlings in the seed bed. The results of only the former experiments are recorded here and an account of the latter is reserved for future publication.

\section{EXPERIMENTS WITH STUCKS.}

These experiments were inaugurated in the spring of 1891 and continued until the fall of 1892 . The stocks planted in 1891 were sprayed both seasons, the design being to ascertain the effects of two consecutive years. The results are here presented briefly and the minor details are to be found at the close of the article. 
All the stocks were sprayel on the same dates; in 1891 on May 21, June 3 and 24, July 9 and 24, and. August 8 and 28. One-half the stocks were treated seven times, on the dates just indicated, and onehalf only three times, on the first three dates named. In 1892 the dates of treatment were May 26-27, June 15-16, June 23, July 6-7 and 21, and Angust 5. One-half were sprayed five times, on the first five dates mentioned, the other half six times as just indicated. The only fungicides used were Bordeaux mixture and ammoniacal solution. In 1891 both preparations were of essentially standard strength, but in 1892 the Bordeaux mixture was reduced to the 60-gallon formula, as explained on a subsequent page (p. 262).

\section{FRENCH PEAR STOCKS.}

1891.-Four rows (1,922 stocks), of which 1,462 were treated and 460 left untreated. One-half the treated stocks were sprayed with ammoniacal solution, the other half with Bordeaux, at the dates above indicated. Although the disease was not so abundant in 1891 as in 1892, the contrast between treated and untreated was striking. Seven treatments with Bordeaux proved efficacious, while neither three treatments with Bordeaux nor seven with ammoniacal solution showed as good results, and three treatments with ammoniacal solution were without apparent effect. On October 9 a count of those stocks forced by the premature fall of the foliage to put forth new leaves gave the following figures:

TABLE 1.-Showing number of French stocks forced to put out new leaves.

\begin{tabular}{|c|c|c|}
\hline Number and treatment of stocks. & $\begin{array}{l}\text { Total re- } \\
\text { leaved. }\end{array}$ & $\begin{array}{l}\text { Per centre. } \\
\text { leaved. }\end{array}$ \\
\hline 388 stocks treated 7 times with Bordeaux....... & 4 & 1.0 \\
\hline 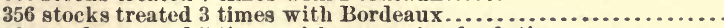 & 55 & 16.4 \\
\hline 361 stocks treated 7 times with ammoniacal solution................ & 50 & 13.8 \\
\hline 357 stocks treated 3 times with anmoniacal solutiou............... & 161 & 45.0 \\
\hline 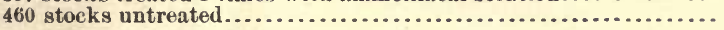 & 97 & 21.0 \\
\hline
\end{tabular}

18.92. - The same rows of stocks as were employed in 1891 were treated in 1892, but one-half of them had been budled the fall previous, as sul). sequently described on pp. 258,261 . The other half was purposely left unbudied to furnish a means of testing the fungicides. The treatments were made on dates given above, using the formulæ mentioned on p. 262. During the course of the season little difference between treated and untreated budded stocks was noticeable, as none but the Flemish Beanty were subject to the disease. At the close of the season, however, the foliage on treated Flemish Beanty was much superior to that on untreated. Bordeaux proved superior to ammoniacal solution and entirely eflicicious.

The greatest contrast in the experiment was between the treated and untreated stocks which had not been budded. The susceptibility of these unbudded seedlings afforded an excellent opportunity to test the 
efficacy of the fungicides, and the results fully warrant the extended use of Bordeaux mixture upon such stocks. As early as June 24 the difference between treated and untreated sections was visible, 75 per cent of thie foliage of the untreated being diseased, while the sections sprayed with Bordeanx mixture remained healthy. Plates xxI and XxII show fairly well the contrast as it appeared on October 11, the two rows standing only $3 \frac{1}{2}$ feet apart. The difference consisted not only in the presence of foliage on the treated and its absence on the untreated, but in an increased grow th of the former, as is shown by weights and measurements of the stocks given below. A calipering of these stocks in 1891 showed no appreciable average difference in diameter.

Diagram 1.-Showing arrangement of treated and untreated rows.

$\frac{\frac{A}{B}}{C} \frac{D}{\frac{E}{F}}$

Explanation OF DIAGRaM 1.

$A$ and B, treated 7 times in 1891 and 6 times in 1892 with Bordeanx; C, control on row opposite; D and E, treated three times in 1891 and 5 times in 1892 with Bordeallx ; $\mathbf{F}$, control on row opposite. This portion of the experiment was situated on rows VI, VII, and VIII, as indicated in Table 2, below, and in the plan on p. 257. The mbudded portion alone is considered.

TABLE 2.-Showing weights and measurements of treated and untreated Freneh pear stoeks in November.

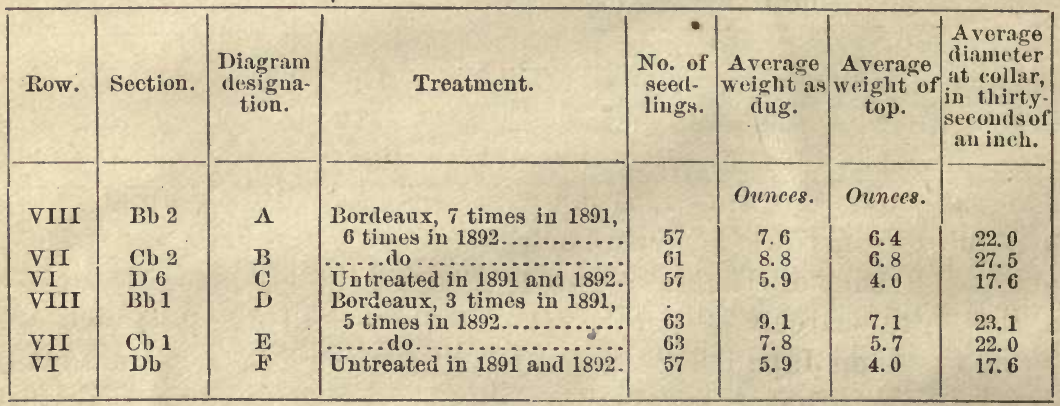

The above data were secured in the following manner: The first week in November each individual stock was dug carefully and the dirt cleaned from the roots. It was then calipered and weighed. The top was then cut off and weighed separately. These data are, perhaps, the first published showing the superiority of treated pear seedlings in other respects than that of foliage. As regards a comparison of the two copper eompounds, it will be sufficient to say that the Bordeaux was in all respects superior to the ammoniacal solution. In the order of their efficacy the four methods of treatment are as follows: Bordeaux, 
6 treatments; Bordeaux, 5 treatments; ammoniacal solution, 6 treatments; ammoniacal solution, 5 treatments. Five treatments with the ammoniacal solution proved almost entirely ineffectual. Plate Xxir shows the average of stocks treated 6 times with ammoniacal solution.

JAPAN PEAR STOCKS.

1891.-One row of 466 stocks was planted in a manner precisely similar to that described for the French stocks. The dates of treatment were as above given, one-half the treated portion receiving three treatments and the other seven, one-half being treated with Bordeaux, the other with ammoniacal solution. The results obtained were striking, as illustrated by the following notes on the re-lerved stocks:

TABLE 3.-Showing number of Japan stocks fored to put out new leaves.

\begin{tabular}{|c|c|c|}
\hline Number and treatment of stocks. & $\begin{array}{l}\text { Total No. } \\
\text { re leaved. }\end{array}$ & $\begin{array}{l}\text { Per cent } \\
\text { re-leaved. }\end{array}$ \\
\hline 87 stocks treated 7 times with Borleanx... & 1 & 1.1 \\
\hline 88 stocks treated 3 times with Bordean $x . . . . . . .$. & 21 & 23.8 \\
\hline 87 stocks treated 7 times with ammoniacal solntion & 15 & 17.2 \\
\hline 90 stocks treated 3 times with ammoniacal solution. & 9 & 10.0 \\
\hline 114 stocks untreated................................ & 47 & 41.2 \\
\hline
\end{tabular}

The average diameter of the stocks near the collar was not perceptibly greater in the treated than in the untreated, the average difference amounting to less than one thirty-second of an inch. The untreated Japan stocks suffered more from the disease than the untreated French stocks.

1892.-The same row of stocks as that employed the previous season was treated, but one-half or more of the stocks were budded in 1891, as described subsequently on pp. 259,261. The treatments given were as described on pp. 262-263. As early as June 24 the unbudded stocks, which had not been treated, showed the disease plainly, every stock being affected. At this date it was evident that the Japan stocks, as introduced from the south, were more susceptible to leaf-blight than the imported French or the native-grown American stocks. The latter were at this date scarcely affected by the disease. From the two years' experiments upon Japan stocks from Franklin Davis \& Co.'s nurseries it seems probable that these when imported from the South will not show any greater immunity from leaf-blight than the French or American stoeks. A more extended experiment, however, is needed to settle this point. The result of treatments with fungicides was as striking as that gained from the French stocks. The foliage on the budded stocks remained reasonably free from the disease until quite late in September when the stocks in the untreated portions began to drop their leaves badly; those treated 6 times with Bordeaux held their leaves almost intact. The Bordeanx proved in general more efficacious than the ammoniacal solution in the treatment of both budded and unbudded stocks, 
and 6 treatments were more effective than 5. But one noteworthy exception existed in the first section treated 5 times with ammoniacal solution, which is possibly explainable by superiority of soil.

Below are given in Table 4 the notes on foliage and caliper made October 19, 1892 :

TABLE 4.-Shoving condition of Japan stocks as rogards foliage and caliper.

\begin{tabular}{|c|c|c|c|c|}
\hline \multirow{2}{*}{ Section.* } & \multirow{2}{*}{ Treatment. } & \multicolumn{2}{|c|}{$\begin{array}{l}\text { Estimated per cent } \\
\text { of foliage dropped. }\end{array}$} & \multirow{2}{*}{$\begin{array}{l}\text { A verage } \\
\text { caliper } \\
\text { of un- } \\
\text { budded at } \\
\text { collar in } \frac{1}{32} \\
\text { of incl. }\end{array}$} \\
\hline & & $\begin{array}{l}\text { Budded } \\
\text { stocks. }\end{array}$ & $\begin{array}{c}\text { Un- } \\
\text { budded } \\
\text { stocks. }\end{array}$ & \\
\hline Aa1 & Ammoniacal solution, 5 treatments. & 0 & 0 & 26.6 \\
\hline Ba1 & 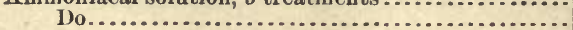 & 0 & 80 & 13.4 \\
\hline Ca1 & Do & 80 & 80 & 15.0 \\
\hline $\mathrm{Aa} 2$ & Ammonical solution, 6 treatments.. & 0 & 50 & 20.3 \\
\hline $\mathrm{Ba} 2$ & 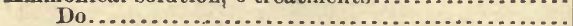 & 0 & 15 & 24.7 \\
\hline $\mathrm{Ca} 2$ & 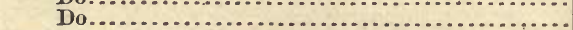 & 85 & 60 & 21.6 \\
\hline $\mathrm{Abl}$ & Bordeaux mixture 5 treatments... & 0 & 10 & 18.7 \\
\hline $\mathrm{Bb} 1$ & 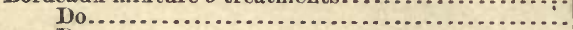 & 0 & 25 & 19.7 \\
\hline Cb1 & Do... & 40 & 50 & 21.3 \\
\hline Ab2 & Bordean $x$ mixture, 6 treatments.... & $\begin{aligned} 40 \\
0\end{aligned}$ & 5 & 21.5 \\
\hline $\mathbf{B b} 2$ & 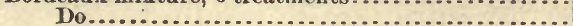 & 0 & 10 & 18.5 \\
\hline Clb2 & Do & 0 & 0 & 23.1 \\
\hline $\mathrm{D}-\mathrm{I}$ & 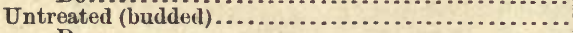 & 15 & …..... & ........... \\
\hline I-1I & Do & 40 & (n........... & (n)............ \\
\hline D-III & 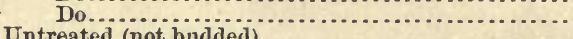 & 95 & $\ldots . . . . .$. & .......... \\
\hline D-IV & Untreated (not buidded) ............................. & & & 13.2 \\
\hline
\end{tabular}

* Designations in this column refer to the varieties of "buds," for details of which, see p. 261.

It is noticeable from the above table that Bordeaux mixture afforded the greatest immunity; also that the untreated unbudded stocks made much less growth than those treated with Bordeaux. A reference to the plan (p. 257) will show the situation of the row (No. IX). When it is remembered that of all of the French stocks, those standing in row VIII only $3 \frac{1}{2}$ feet distant, made the best growth, the element of soi] difference is bardly to be considered as a disturbing factor.

AMERICAN PFAR STOCKS.

1891.-Four rows containing 1,673 stocks were subjected to a course of treatment similar in every respect to that given the French and Japan stocks. Owing to the lateness of the season when application was made to the growers of American seedlings only second-grade stocks were to be obtained. Because of this unfortunate but unavoidable circulıstance no comparison could be drawn as to the comparative value of American, Japan, and imported French stocks. The results of the treatments with fungicides while not as striking as with the French stocks, are valuable as adding testimony to the efficacy of the Bordeaux.* Seven treatments with this mixture proved entirely efficacious, raising the percentage of stocks wholly free from the disease from two-tenths of 1 per cent to 39 per cent. On October 9 a count was ni:ale of the 
number of stocks in each section which pushed out new reares because of the severity of leaf-blight. The results of this comA OAf Itt follows:

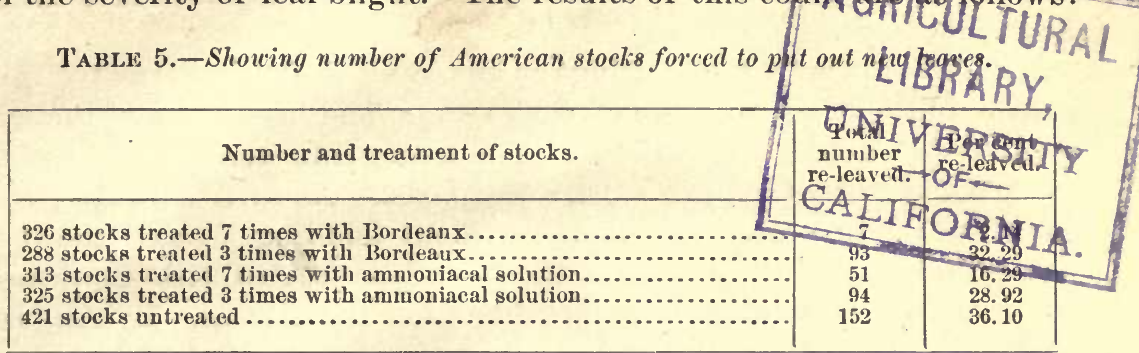

1892.-The same rows of stocks were employed this season as had been treated the previous season, as many as possible of them having been budded as described subsequently on p.261. Those not budable were left standing for further treatment with fungieides. The treatments were as deseribed on pp. 262-263. Owing to the inferior character of the stocks originally planted this whole block would be consilered worthless, as not one-half the stocks were budable in 1891. The effect of the Bordeanx mixture, however, was plainly observable and a rough estimate made October 19 of the percentage of foliage still upon the unbudded stocks shows the Bordeaux to be much superior to the ammoniacal solution, and 6 treatments superior to 5 .

\section{QUINCE LEAF-BLIGHT (Entomosporium maculatum Lév.).}

Much that was said in reference to pear leaf-blight applies equally well to quince leaf-blight, which is caused by the attacks of the same fungus. The parasite, so far as the author's observation goes, never attacks the bark on the young shoots but is confined wholly to the foliage. The Angers quince seems more susceptible than the Orange and it is rare to observe after the first week in September a block of quince enttings from which at least 50 per cent of the leaves have not fallen. Unlike the disease on the pear, the quince leaf-blight often seriously defoliates bearing trees in this section and commonly causes the fruit-grower much loss from its attacks on the ripening fruits, in which form it is called "fruit spot."*

The experiments in the prevention of this disease were confined to one row of Angers quince cuttings, treated partly with Bordeaux mix. ture and partly with ammouiacal solution. $\dagger$

\section{ANGWRS QUINCE STOCKS.}

1891.- One row of 509 cuttings was planted and treated with fungicides in the manner described on pp. 260-263. The season being an unusually dry one, no disease of any consequence appeared, and as

"Bull. 3 Div. Veg. Path., pp. 65-68, Pl. VII, Vill.

t For formulæ of fungicides and dates of treatment, see pp. 262-263. 
stated in a previous publication* the insignificant quantity of leaf blight present offered no opportunity to test the fungicides in a satisfactory manner.

1892.-The same row of cuttings as employed in 1891 was treated this season, but one-half or more of each section had been budded the fall previous, as noted below, p. 260 . The treatments were identical with those made upon the pear stock; see p. 262. As early as July 7 the leaves on the untreated section left without budding showed the dis. ease plainly, while the foliage of those sections treated with Bordeaux and ammoniacal solution remained free from the disease. By August 30 two-thirds of the foliage of the unbudded, untreated portion had fallen to the ground, while the treated sections standing in the same row, as shown in the plan, p. 257, row $\mathrm{V}$, remained intaet. Plates XXIV and $X X V$ show the appearance of the treated and untreated sections.

On September 29 the difference manifested by these stocks was not one of foliage only. The twigs of the treated, upon close examination, were apparently a trifle more robust, and the caliper of the cuttings at the base showed a considerable increase not to be attributed to differences in soil. Below are given the data secured from a careful calipering of the unbudded stocks at the collar, made October 15 . The figures given are in thirty-seconds of an inch and represent the average diameter of stocks in each section:

TABLE 6.-Showing average caliper of treated and untreated unbudded quince stocks.

\begin{tabular}{|c|c|c|}
\hline Section. & Number and treatment of stocks. & $\begin{array}{l}\text { Average } \\
\text { diameter. }\end{array}$ \\
\hline Aal & 16 stocks treated 5 times with ammoniacal solution............. & 25.3 \\
\hline Bal & 16 stocks treated 5 times with ammoniacal solution.............. & 26.2 \\
\hline Ca1 & 16 stocks treated 5 times with ammoniacal solution................. & 26.3 \\
\hline $\mathrm{Aa2}$ & 15 stocks treated 6 times with ammoniacal solution $\ldots \ldots \ldots \ldots \ldots \ldots$ & 25.0 \\
\hline $13 a_{2}$ & 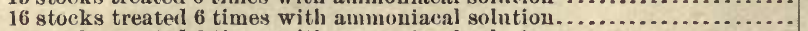 & 27.0 \\
\hline $\mathrm{Ca2}$ & 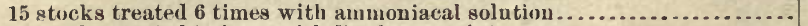 & 24.0 \\
\hline ab1 & 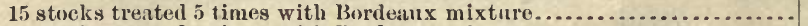 & 27.0 \\
\hline $\mathrm{Bbl}$ & 16 stocks treated 5 times with Burdeaux mixture........................ & 25.2 \\
\hline $\mathrm{Cb} 1$ & 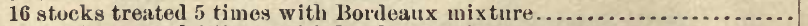 & 252 \\
\hline $\mathrm{Ab} 2$ & 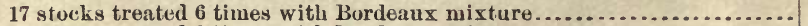 & 29.2 \\
\hline Bb2 & 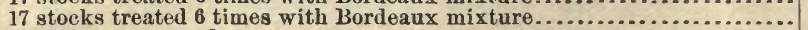 & 26.4 \\
\hline * Div & 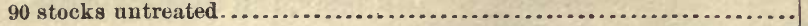 & 20.6 \\
\hline
\end{tabular}

* Unfortunately a section, Cb2, was not staked off in planning the experiment.

The inference from the above table is that the stocks which held their leaves throngh the season made a greater growth in diameter than those from which the foliage dropped in July and Angust. Taking the average of all stocks treated with ammoniacal solution, 94 in number, we lave 25.7 thirty-seconds of an inch, while the average of 81 stocks treated with Bordeaux was 26.5 thirty-seconds. The better of these two averages (26.5) when compared with the untreated (20.6) gives an increase in diameter of 5.9 thirty-seconds or nearly three-six teenths of an inch. 


\section{CHERRY LEAF-BLIGHT (Cylindrosporium padi Karsten).}

The leaf-blight of cherries' eaused by the same species of fungus as that producing plum leaf-blight, is very widespread. Scarcely a wild species of the genus Prunus is entirely exempt from the disease, and at all stages from seedlings in the seed bed to old bearing trees, cultivated cherries are subject to its attacks. The greatest variation exists, however, as regards the susceptibility of different varieties, some being nearly exempt and others, as the English Morello, materially damaged by it. Remarkable eases of immunity are sometimes observed. Of seedlings used for budding, only the Mazzard seems in any serious degree damaged by the disease. In unfavorable years the defoliation is so serious as to render the first year's growth of stocks almost insignificant. Mazzard seedlings of the second year are also badly attacked. The greatest damage probably occurs where Mazzard stocks are budded with susceptible varieties, in which ease the cumulative effects of the disease appear. It should bo noted here, however, that the cherry leaves attacked by the parasite remain attached to the stocks long enongh to take on the yellow antumn tints characteristic of foliage from which the valuable ingredients of potash and phosphoric acid have been removed.* It is probable, although no experiments have to my knowledge been made to establish it, that the premature fall of the leaves does not entail so great a loss to the cherry seedling as does the fall of the pear foliage, which drops while still green.

The experiments in the prevention of this disease, extending over a period of two seasons, were made upon the two well-known kinds of stocks, Mahaleb and Mazzard. In 1891 only the stocks not yet budded were treated, while in 1892 the stocks budded in the fall of 1891 were sprayed, suitable control being left.

For record of budding see pp. 258, 260. Bordeaux mixture and ammoniacal solution of standard strength were employed in 1891; ammoniacal solution of standard strength and Bordeaux of one-third strength in $1892 .+$

MAHALEB CHERRY STOCKS.

1891.-One row of 449 stocks was planted and treated with fungieides at the dates described for all the stocks on p.263. One-half, excepting controls, received 6 and the other 3 sprayings. One-half were treated with ammoniacal solution, the other with Bordeaux. As meutioned in Bulletin No. $3, \ddagger$ where an account of this experiment has already been

*According to the prevailing views of the physiological botanists, Pfeffer, Sachs, Detmer, Wiesner, and others, the valuable mineral constituents of leaves are withdrawn from them at the same time as they become yellow and before they fall to the ground; but the recent paper of Wehmer, Die dem Laubfall voraufyehende vermeintliche Blattentleerung. <Ber. d. deutsch. bot. Gesellsch. 10 Jahrg., Heft. 3, pp. 159-163, indicates that the grounds for this belief may not have-been sutticiently proven, and the whole subject needs further investigation.

t See p. 262 for formulio of all fungicides used.

†Op. cit.; p. 58. 
given, the leaf-blight was not present in any considerable amount dur. ing the season and the efficacy of the two fungicides was not given a test of any severity. The treated portions, however, remained freer from disease than the untreated.

18.92.-The same row which had been budded in the fall of 1891 as described subsequently, was treated this season in a manner precisely similar to that described for the pear stocks on page 263. Care was taken that the undersicles of the leaves were wet by the spray and to accomplish this the Vermorel nozzle was directed upwarls. On June 24 the first signs of leaf-blight were noticed upon the budded, untreated, stocks, the unbudded stocks remaining almost entirely free throughont the season. By July 16 the leaves of the untreated began to fall and continued dropping until many of the stocks were left nearly leafless. On October 4 a careful count was made of the number of leaves which had fallen from each individual stock in the row. This was accomplished, in a comparative way, by counting the leaf-scars on each stock. Below is given for convenience a condensed statement of the condition of the stocks with regard to height, diameter 3 inches above the union, and freedom from leaf-blight. All numbers represent averages. Height above ground (measured September 28) is represented in feet and inches, while the figures for diameter (measured October 15) are in thirty-seconds of an inch. Only budded stocks are here taken iuto account.

TABLE 7.-Showing condition of budded Mahaleb stocks, treated and untreated, as regards foliage and measurements.

\begin{tabular}{|c|c|c|c|c|c|}
\hline Section: & Numbers, kinds, and treatment of stocks. & $\begin{array}{c}\text { Average } \\
\text { number } \\
\text { of leaves } \\
\text { fallen } \\
\text { ()etober } 4 .\end{array}$ & $\begin{array}{c}\text { Ave } \\
\text { height } \\
\text { gro }\end{array}$ & $\begin{array}{l}\text { rage } \\
\text { above } \\
\text { and. }\end{array}$ & $\begin{array}{l}\text { Average } \\
\text { caliper } \\
3 \text { inches } \\
\text { above } \\
\text { union. }\end{array}$ \\
\hline Aa 1 & $\begin{array}{c}16 \text { budded Windsor stocks. Ammoniacal, } 5 \\
\text { treatments }\end{array}$ & & & $\begin{array}{l}\text { Inches. } \\
8\end{array}$ & \\
\hline Aa 2 & 18 budded Windsor stocks. Ammoniacal, 6 & & & & 23 \\
\hline $\mathrm{Ab} 1$ & 13 budded W indsor stocks. Bordeaux, 5 treat- & 7.8 & 5 & 10 & 23 \\
\hline $\mathrm{Ab}_{2}$ & $\begin{array}{l}\text { ments } \\
17 \text { budded windsor stocks. Bordeaux, } 6 \text { treat- }\end{array}$ & 13.1 & 6 & 0 & 24 \\
\hline & 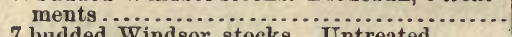 & $7 \cdot 4$ & 6 & 0 & 25 \\
\hline Ba I & 7 budded Windsor stocks. Untreated ........ & 54.8 & 5 & 0 & 16 \\
\hline $13 \mathrm{a} 2$ & 17 budded Yellow Spanish stocks. Ammoni- & 6.4 & 4 & 9 & 22 \\
\hline Bb 1 & $\begin{array}{l}\text { acal, } 6 \text { treatments...................................... } \\
18 \text { budded Yellow Spanish stocks. }\end{array}$ & 6.4 & 4 & 9 & 21 \\
\hline Bb 2 & 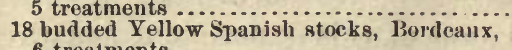 & 7.3 & 5 & 4 & 21 \\
\hline $\begin{array}{l}\text { D-II } \\
\text { Ca } 1\end{array}$ & $\begin{array}{l}8 \text { budded Yellow Spanish stocks. Untreated. } \\
16 \text { budded Montmorency stocks. A mmoniacal, }\end{array}$ & 21.8 & 4 & $\begin{array}{l}1 \\
1\end{array}$ & 16 \\
\hline Ca 2 & $\begin{array}{l}5 \text { treatment } \\
18 \text { budded Montmorency stocks. Ammoniacal, }\end{array}$ & 8.5 & 3 & 7 & 21 \\
\hline $\mathrm{Cb} 1$ & $\begin{array}{l}6 \text { treatments } \\
22 \text { budded Montmorency stocks. Bordeaux, }\end{array}$ & 10.3 & 3 & 5 & 21 \\
\hline $\mathrm{Cb} 2$ & 16 budded Montmorency stocks. Bordeaux, & & 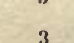 & $"$ & 19 \\
\hline D-I & 4 budded Montinorency stocks. Untreated... & 65.7 & 3 & B & 17 \\
\hline
\end{tabular}


The conclusion which can be drawn from the table seems to be that the treated sections held their leaves better, made as good a growth in height, and without exception a greater growth in diameter, or "caliper," than the untreated sections. That this increased growth was flue entirely to the fungicide it will not be possible to maintain, for this difference may possibly have been brought about in part or wholly by variations in the soil. That none of the mixtures injured the "buds" it is believed is clearly shown.

The answer to question 3, as to the effect of fungicides on the growth of budded stocks is here, for the Bordeaux mixture at least, satisfactorily found, for both Windsor and Yellow Spanish stocks did better under treatment with Bordeaux than without treatment. There still remains a doubt as to the beneficial effect of ammoniacal solution. In all eases where used it was apparently slightly injurious to the foliage. The leaves assumed a yellowish unhealthy appearance. Plates XXVI and XXVII show the comparison between treated and untreated "buds."

\section{MAZZARD CHERRY STOCKS.}

1891.-One row of 468 stocks was experimented with, receiving as nearly as possible a course of treatment identical with that given the Mahaleb stocks. During the season, as in the ease of the Mahalebs, only an insignificant amount of leaf-blight was present. affording no opportunity to test the fungicides. The powdery mildew (Podosphara oxyacanthce (DC.) Winter ?) made its appearance in small amount on the stocks in August and offered an opportunity to observe the beneficial effects of Bordeaux mixture in the treatment of this disease. Seven treatments with Bordeaux materially decreased the amount of the disease and proved superior to seven treatments with ammoniacal solution.* Three early treatments with either fungicide had no preventive effect.

1892.- The same row as that treated in $\mathbf{1 8 9 1}$ was used this season, but budded with three different varieties identical with those budded on the Mahaleb stocks as shown in the table on p. 260. The treatments were similar in all respects to those given the Mahaleb stocks. The condition of the stocks at the close of the season is shown by the following table: 
TABLE 8. - Showing condition of budded Mazzard stocks treated and untreated as regards folinge and measurements.

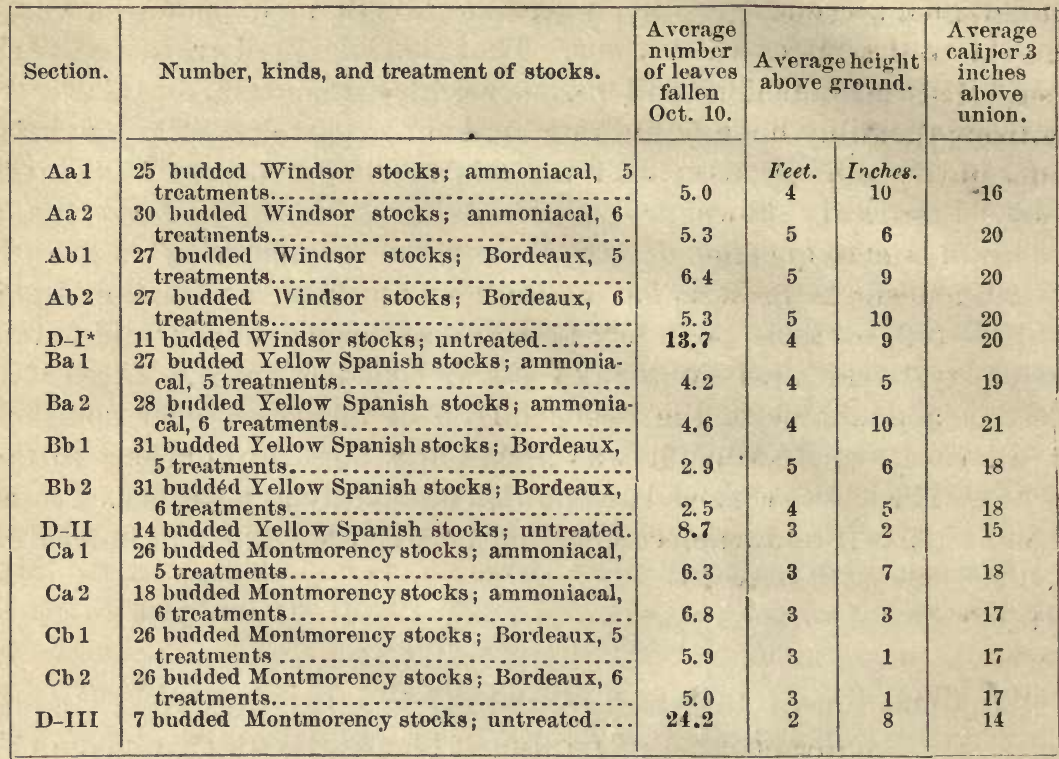

* By an accident this section received one late spraying with Bordeaux and hence it is rendered unfit for comparison.

The disease did comparatively little damage upon these stocks, but as shown by the table, the treated sections were superior to the untreated, and the Bordeaux slightly superior to the ammoniacal solution when 6 treatments are compared.* The difference between 5 and 6 treatments was not very marked.

A comparison of the two tables brings ont the fact which is noteworthy in this connection, that the "buds" $f$ on Mahaleb stocks averaged greater in diameter throughout than those on the Mazzard. This difference is constant when stocks receiving the same treatment are compared in each row, with the exception of the untreated section of Windsors when compared with that treated once by mistake. This constant difference in diameter, at 3 inches above the base ("caliper"), is of such importance as to merit further observations. The author regrets that the control rows were left so small, and feels warranted in draiwing only the general conclusion, which was strikingly demonstrated that the fungicides were effective to a remarkable degree in preventing the disease and that treated stocks made the best growth.

* The superiority of Bordeanx is not fully shown by the figures, as in every case the effect of the ammoniacal solution was evidently injurious to the health of the foliage.

†The term "bud" is here used, as among nurserymen, to indieate a budded stock after the top has been cut off and the inserted bud itself allowed to grow. 
The plum leaf-blight in western New York, aside from giving much trouble to nurserymen, does very great damage to many varieties of bearing trees, defoliating them in August and September. This disease is considered-by the plum-growers in the vicinity of Geneva as their most persistent enemy. A large orchard belonging to E. Smith \& Sons, 2 miles northwest of the eity, was, they informed me, winter-killed about thirty years ago because of defoliation the summer previous. It is a common opinion among orchardists that leaf-blight, through its retarding effect upon the maturation of the wood, renders the trees incapable of withstanding the changes in temperature of a trying winter. Whatever the explanation of this fact may be, it seems self-evident that a tree which drops its leaves before the normal season suffers very material loss.

Of nursery stocks, the native-grown seedlings suffer the most fiom this disease, often losing all their leaves by the middle of August. Myrobolan and Marianna stocks are not to any extent subject the first season. In entire contradistinction to the immunity exhibited by pear "buds" which resist to a remarkable degree pear leaf-blight, the budded plum stocks are particularly susceptible to plunn leat-blight. A pparently the same conditions of rapid grow th which afford immunity in the one case tend to susceptibility in the other. The two instances offer a fertile field for inquiry.

The experiments on this disease were made with Bordeaux mixture and ammoniacal solution upon two rows of stocks, one of Mariamna, containing 504 stocks, and the other of Myrobolan, containing 474 stocks. As described previously * the results of the first season's experiment were entirely negative, as the disease failed to appear.

(On October 9 the three varieties, Early Prolific (Early Rivers), Purple Egg (Hudson River Purple Egg), and Italian Prune (Fellenburg), were budded upon both rows of stocks as set forth subsequently, p. 258 . Numerous stocks were left unbudded to test the effect of the fungicides and the end of each row was left untreated.

The rows were treated in 1892 with Bordeanx and ammoniacal solution, the formula of which are described on p. 262. One-half the treated stocks received 5 sprayings and the other 6 , at the dates given on p. 243. In all respects the two rows were treated alike.

MYROBOLAN STOCKS.

1892.-The disease made its first appearance in June upon the unbudded stocks which were earried over from 1891, and strangely enough only upon the treated portions. This dropping of the treated Myrobolan foliage was confined to the leaves situated on the larger 
limbs in the interior portion of the bushy growtn. Althongh only a small per cent of the foliage was thus affected, the difference between treated and untreated was quite evident. After the lapse of three or four weeks this falling of the leaves ceased. The unbudded stocks which were not treated remained remarkably free from the disease, but in this respect were excelled by the Marianna unbudded, untreated stocks. The budded stocks were not so soon affected as the unbudded, but the Early Prolific "buds" in the untreated section began dropping their foliage in July and throughout the season were manifestly worse affected. The following table shows the data collected in September and October, after all growth had practically ceased:

TABLE 9.-Showing condition of budded Myrobolan stocks treated and untrcated, as regards foliage and mersurements.

\begin{tabular}{|c|c|c|c|c|c|}
\hline Section. & Number, kinds, and treatment of stocks. & $\begin{array}{l}\text { Average } \\
\text { number } \\
\text { of leaves } \\
\text { falleu Oe- } \\
\text { tober } 10 .\end{array}$ & $\begin{array}{c}\text { Av } \\
\text { heigl } \\
\text { grout } \\
\text { tem }\end{array}$ & $\begin{array}{l}\text { rage } \\
\text { above } \\
\text { d Sep- } \\
\text { er } 28 \text {. }\end{array}$ & $\begin{array}{l}\text { Average } \\
\text { caliper3in- } \\
\text { chesabove } \\
\text { union, Oc- } \\
\text { tober } 15 \text {. }\end{array}$ \\
\hline Aa1 & 11 budded Early Prolific stocks, ammoniacal, & & Feet. & Inches. & \\
\hline & 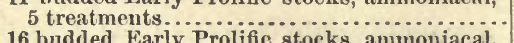 & 69.8 & 3 & 6 & 14.8 \\
\hline Aa2 & 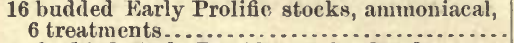 & 115.8 & 3 & 6 & 14.3 \\
\hline Ab1 & 18 budded Early Prolific stocks, Borcleaux, 5 & & & & \\
\hline $\mathrm{Ab2}$ & 13 budded Early Prolific stocks, Bordeaux, 6 & 66. & 4 & .0 & 15.4 \\
\hline D-I & 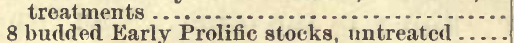 & 57.5 & 3 & 8 & 16.9 \\
\hline Ba1 & 13 budded Purple Egg stocks, ammoniacal, 5 & 312.5 & 3 & 9 & 14.3 \\
\hline $\mathrm{Ba} 2$ & $\begin{array}{l}\text { treatments } \\
20 \text { budded Purple } \mathrm{Egg} \text { stocks, ammoniacal, } 6\end{array}$ & 36.3 & 4 & 1 & 16. 2 \\
\hline & 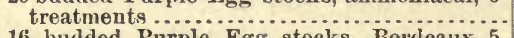 & 32.8 & 4 & 2 & 15.1 \\
\hline Bb1 & 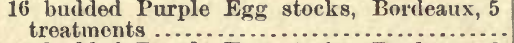 & 6.1 & 3 & 8 & 15.4 \\
\hline $\mathrm{Bb2}$ & 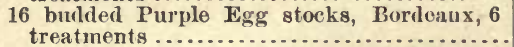 & & 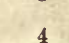 & 3 & \\
\hline D-II & 10 budded Purple Egg stocks, untreated ...... & 123.3 & 4 & 7 & 16.4 \\
\hline $\mathrm{Ca} 1$ & 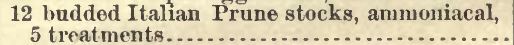 & 15.8 & 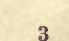 & 10 & 14.3 \\
\hline $\mathrm{Ca2}$ & 16 buddod Italian Prune stocks, amuoniacal, & & & & \\
\hline Cb1 & $\begin{array}{l}6 \text { treatments................................... } \\
16 \text { budded Italian Prune stocks, Bordeaux, } 5\end{array}$ & 8.2 & 3 & 7 & 15.3 \\
\hline $\mathrm{Cb}_{2}$ & $\begin{array}{l}\text { treatments } \\
15 \text { budded Italian Prune stocks, Bordeaux, } 6\end{array}$ & 7.8 & 3 & 6 & 15.5 \\
\hline 202 & 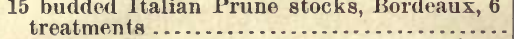 & 6. 3 & 4 & 0 & 16.4 \\
\hline D-III & 11 budded Italian Prune stocks, untreated.... & 52.8 & 3 & 9 & 15.0 \\
\hline
\end{tabular}

From this table the only conclusion admissible is in regard to the amount of leaf-blight. It is evident that the treated portions lost only a small number of leaves in comparison with the untreated, and in so far the fungicides proved effective.

MARIANNA STOCKS.

1892.-The treatment of these stocks was in all respects identical with that of the Myrobolan stocks and the results were in general similar. The treated unbudded stocks lost a number of their leaves from an early attack of the fungus in June and July, but the untreated unbudded portion of the row remained remarkably free from the disease throughout the season, more so in this regard than the Myrobolan. The 
budded stocks showed little superiority in regard to leaf-blight over the budded Myrobolan and evidently no considerable degree of immunity was afforded by the stock to the scion. But a comparison of the two tables brings out the fact that the Purple Egg "buds" made markedly the best growth upon Marianna stocks. These "buds" averaged more than one-eighth of an inch greater in diameter and were on an average 10 inches higher. The other less rapidly growing stocks did not show such a marked difference, and too much reliance ought not to be placed on data gathered from so small a number of stocks. Certain it is, however, that the Marianna proved superior in this single experiment.

TABLE 10.-Showing condition of budded Marianna stocks, treated and untreated, as regards foliage and measurements.

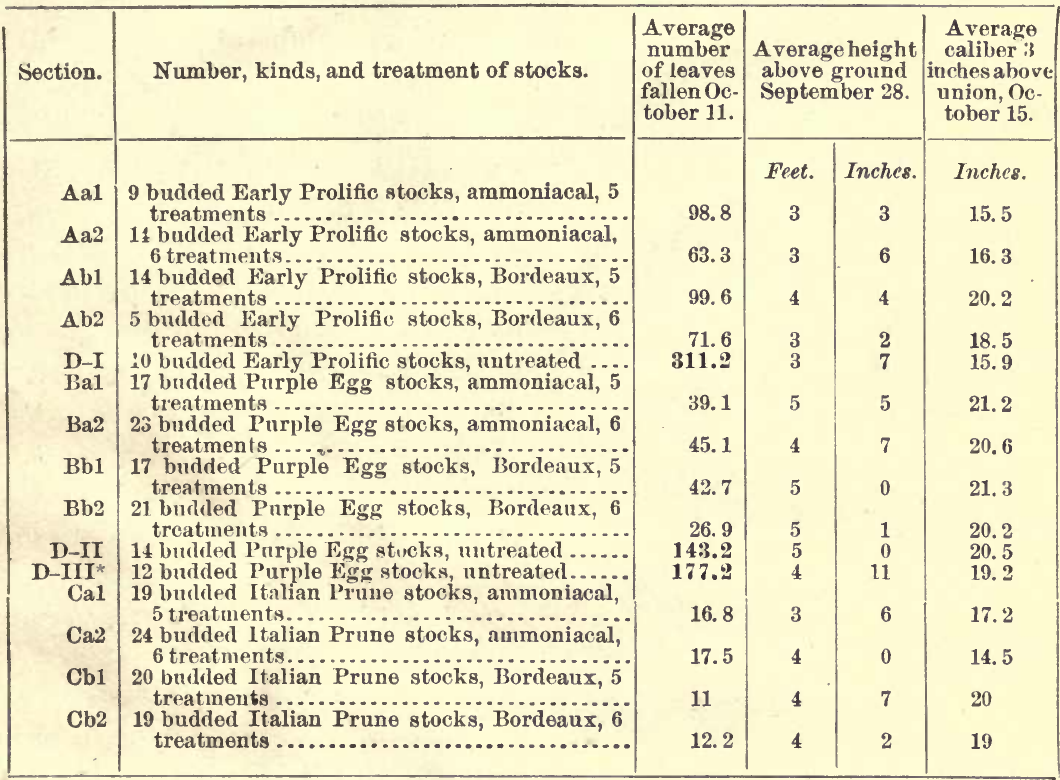

^ By another mistake in budding, those stocks which should have received Italian Prune buds were budded with Purple Egg buds.

As regards the effects of the treatments, the only fairly deducible conclusion is that the Borleaux mixture and ammoniacal solution prevented the disease to a notable degree, sufficient, it is believed, to warrant further extended trial in nursery practice. Although not evident from the table, the ammoniacal solution is in reality inferior to Bordeaux, as it injures the foliage of the treated "buds." On this account it can not be recommended for the treatment of plum stocks. Plates XXVIII and XXIX show the treated and untreated "buds" as they appeared in the experiments. 
Seedling apples sometimes suffer quite severely from this disease, which attacks their young shoot tips, often stunting the growth of the seedlings and preventing them from attaining a suitable size the first season. Compared with the injury caused by the apple thrips, however, that brought about by mildew is surely insignificant and, in New York State at least, hardly warrants any expensive measures for its prevention. The disease usually appears late in September, when the principal growth has been made, and seldom, if ever, sprearls to vigorously growing budded stocks, even when these are in close proximity to diseased seedlings. The malady was not observed on bearing trees in the neighborhood of Geneva.

The experiments for the prevention of this disease comprised in 1891 about 1,000 American stocks and the same number of French stocks, besides 500 seedlings. As stated in a previous publication,* the results of the first season's treatment of the stocks was entirely negative and the treatments of seedlings which were made on May 21, June 3, 24, July 9, 24, and August 8, as well as the early treatments made on the first three dates mentioned, failed entirely to prevent the appearance of mildew the first week in September. Bordeaux mixture and ammoniacal solution alone were used, the formulæ being those described on p. 262. This failure of the fungicides is considered by the author merely as additional testimony to the fact observed that the mixtures were largely washed off before the disease appeared. On August 7 the French and American stocks were budded with Twenty Ounce, Fameuse and Early Strawberry buds, as described in detail on p. 259, and in the season of 1892 the budded, and such of the stocks as were left unbudded were treated with Bordeaux mixture and ammoniacal solution at dates the same as for all other stocks, viz, May 27; June 16, 23; July 7, 21; and August 5. One-half the treated stocks were sprayed 5 times on the first five dates mentioned, the other half were sprayed 6 times.

No powdery mildew appeared during the course of the season, and in October the results of the treatments were entirely negative. The apple thrips, however, attacked the budded and unbudded stocks and injured them severely. The mixtures had, as might be expected, no effect upon these insects.

\section{DETAILS OF THE EXPERIMENTS.}

The following pages comprise the details of the experiments, which are removed from the general account in order to render the latter more comprehensible. They will prove of interest only to specialists on the subject. 
Dragram 2.-Plan of nursery cxperiment at Genera, $N$. $\boldsymbol{Y}$.

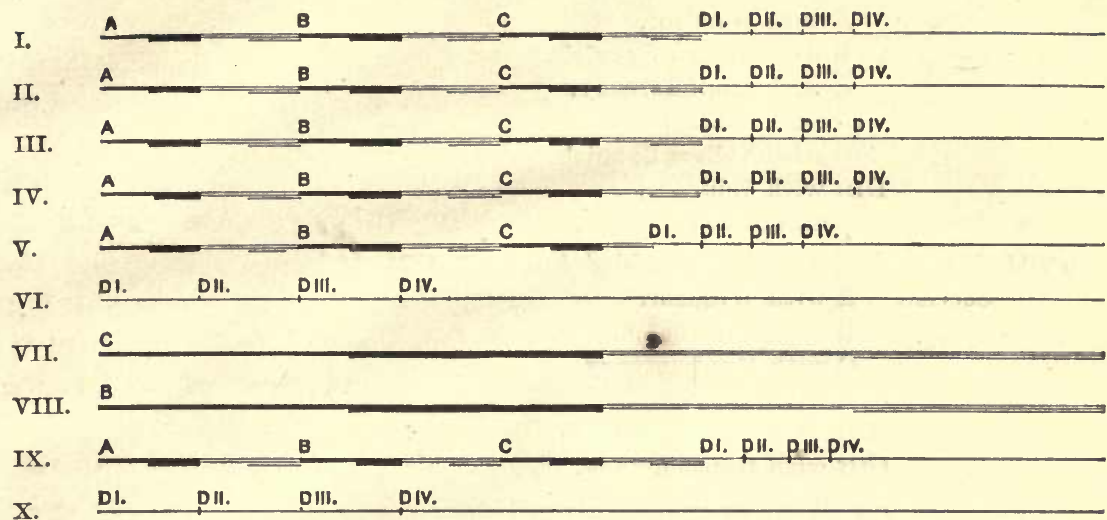

XI.

XII. B

XIII. A

XIV. c

OI. DII. DIII. DIV.

$\mathrm{XV}$.

B

XVI.

DI. DII. DIII. OIV.

XVII. A

B

$\mathrm{xx}$.

A B

c

DI. DII. PIII. pIV.

XVIII

XIX.

PeAR SeEd-Worthless.

XXI. A

XXII.

XXII

\footnotetext{
- Treated 3 to 5 times with ammoniacal solution, (a 1).

- Treated 6 to 7 times with ammoniacal solution, ( $a 2$ ).

= Treated 4 times with mixture No. 13.

Untreated.

Treated 3 to 5 times with Bordeaux, (b 1).

Treated 6 to 7 times with Bordeaux, $(b 2)$.
}

The actual proportions of the experimental field do not admit of any but a diagrammatic representation. The location of the field is designated in the records of the station as "main farm plat B." The rows ran east and west, the west end of each row being indicated by a Roman numeral. These numerals are for convenience of reference (see account following). The capital letters heading the sections of each row refer to the budding. For example: Row I, Section A, was budded with Windsor; Row I, Section B, with Yollow Spanish, precisely as set forth below. The treatments with fungicides which each section and subsection received are in.licated by the key below Diagram 2. 
The sections of the various rows were budded as below described.

Row I. Mahaleb cherry stocks budded August 5, 1891.

Section A with Windsor.

B with Yellow Spanish.

C with Montmorency.

Di with Montmorency.

DrI with Yellow Spanish.

Din with Windsor.

Drv unbudded.

Row II. Mazzard cherry stocks budded August 5, 1891.

Section A with Windsor.

B with Yellow Spanish.

C with Montmorency.

DI with Windsor.

DiI with Yellow Spanish.

DiII with Montmorency.

Div unbudded.

Row. III. Myrobolan plum stocks budded September 10, 1891.

Section A with Early Prolific.

B with Purple Egg.

C with Italian Prune.

DI with Early Prolific.

Dir with Purple Egg.

DiII with Italian Prune.

Drv unbudded.

Row IV. Marianna plum stocks budded September 10, 1891.

Section A with Early Prolific.

B with Purple Egg.

C with Italian Prune.

DI with Early Prolific.

Dir with Purple Egg. *

DuI with Purple Egg.t

Div unbudded.

Row V. Angers quince stocks budded August 6, 1891.

Section A with Duchess.

B with Anjou.

C with Flemish Beauty.

Dr with Duchess.

Dir with Anjou.

Dirr with Anjou.

Drv unbudded.

Row VI. French pear stocks budded August 7, 1891.

Section Dr with Duchess.

DiI with Anjou.

DiII with Flemish Beauty.

Drv unbudded.

Row VII. French pear stocks budded August 7, 1891.

Section $\mathbf{C}$ with Flemish Beauty.

Row VIII. French pear stocks budded August 7, 1891.

Section B with Anjou.

* A variety of recent introduction originated on the Hudson River.

† The budder's blunder in inserting these in place of Italian Prune. 
Row IX. Japan pear stocks budded Angust 5, 1891.

Section
A with Duchess.
B with Anjou.
C with Flemish Beauty.
Dr with Duchess.
Dir with Anjou.
Dir with Flemish Beanty.
Div unbudded.

Row X. Anerican pear stocks budded Angust 7, 1891.

Section DI with Duchess.

DII with Anjou.

Din with Flemish Beauty.

Div unbudded.

Row XI. American pear stocks budded August 7, 1891.

Section C with Flemish Beauty.

Row XII. American pear stocks bndded August 7, 1891.

Section B with Anjou.

Row XIII. American pear stocks budded Angust 7, 1891.

Section A with Duchess.

Row XIV. American apple stocks budded August 7, 1891.

Section C with Twenty Ounce.

Di with Fameuse.

DII with Early Strawberry.

Diri with Twenty Ounce.

Div unbudded.

Row XV. American apple stocks budded August 7, 1891.

Section A with Famense.

B with Early Strawberry.

Row XVI. French apple stocks budded August 7, 1891.

Section C with Twenty Ounce.

Di with Fameuse.

DII with Early Strawberry.

Dirl with Twenty Ounce.

Drv unbudded.

Row XVII. French apple stocks budded August 7, 1891.

Section A with Fameuse.

B with Early Strawberry.

Row XVIII. French apple seeds.

Row XIX. French pear seeds which did not germinato.

Row XX. Peach seedlings which remained healthy.

Row XXI. French pear stocks budded August 7, 1891.

Section A with Duchess.

Row XXII. Plum seedlings of Prunus domestica.*

Row XXIII. Horse chestnut seedlings."

* The results of treatments of plum and horse chestuut seedlings are reserved for future publication. 
TABLE 11.--Showing the number of budded stocks in each treated and untreated section.

[The small letter $a$ indicates that the stoeks were treated with ammonical solution, the letter $b$ that they were sprayed with Bordeaux. 'The Arabie numeral 1 indicates that the stocks were treated 5 times, the number 2 that they were treated 6 times. 'The sections marked I-IV were not treated. ]

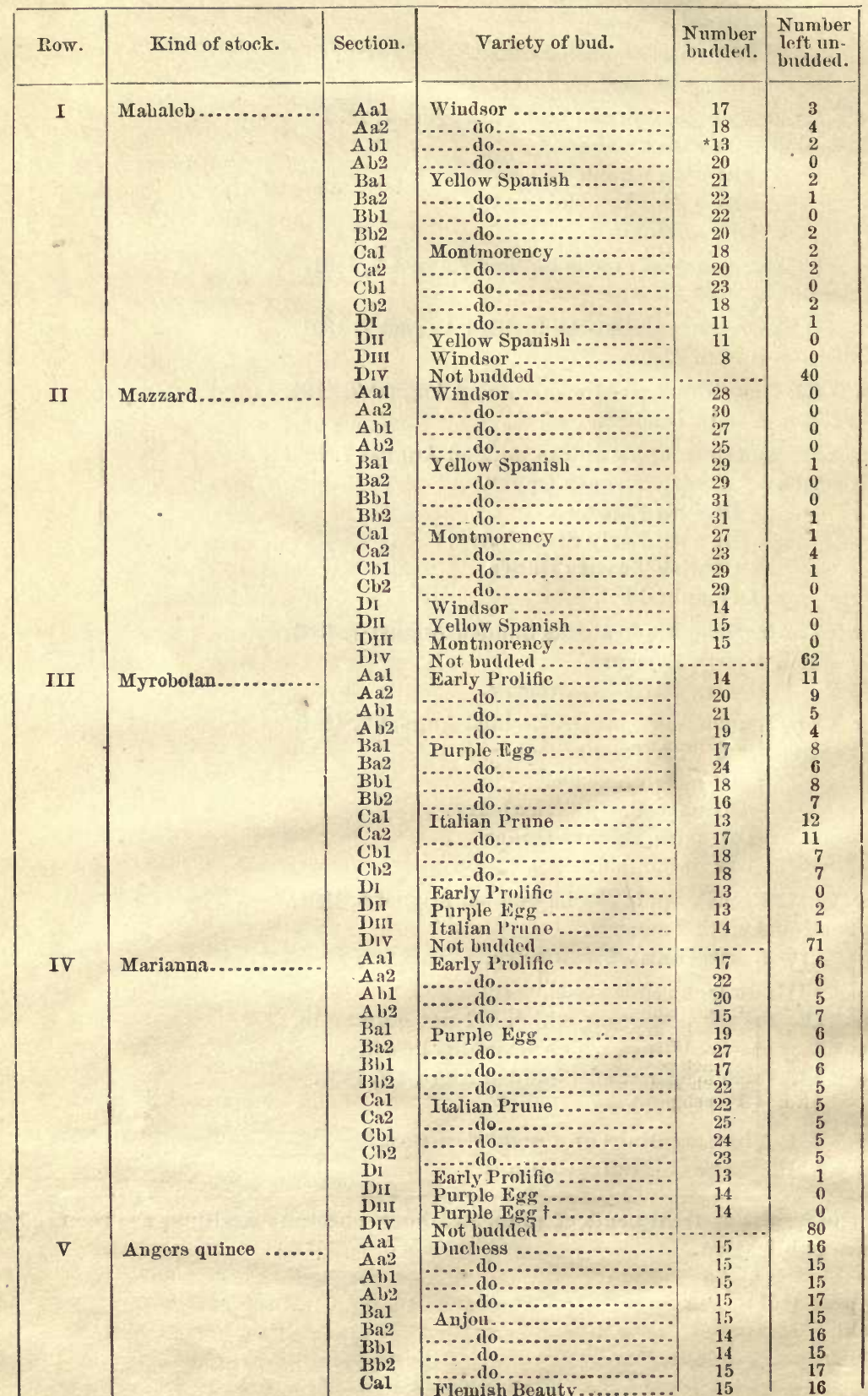

* Five bads of the Montmorency were inserted by mistake of the budder. t Should have been Fellenburg-mistake of budder. 
TABLE 11.--Showing the number of budded stocks in each treated and untreated sectionContinued.

\begin{tabular}{|c|c|c|c|c|c|}
\hline Row. & Kind of stock. & Section. & Variety of bud. & $\begin{array}{l}\text { Number } \\
\text { budded. }\end{array}$ & $\begin{array}{l}\text { Number } \\
\text { left un- } \\
\text { budded. }\end{array}$ \\
\hline \multirow[t]{6}{*}{$\mathbf{V}$} & Angers quince ....... & $\mathrm{Ca} 2$ & Flemish Beauty............ & 15 & 14 \\
\hline & & Cb1 & 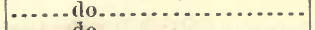 & 15 & 16 \\
\hline & & $\mathrm{Cb} 2$ & .... do........................... & 15 & . $\mathbf{0}$ \\
\hline & & D1 & Dnchess $\ldots . . . \ldots \ldots \ldots \ldots . . . .$. & 15 & 0 \\
\hline & & DII & Anjou $\ldots \ldots \ldots \ldots \ldots \ldots \ldots$ & 14 & 1 \\
\hline & & $\begin{array}{l}\text { DIII } \\
\text { DiY }\end{array}$ & 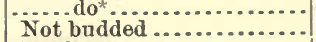 & 15 & $\begin{array}{r}0 \\
97\end{array}$ \\
\hline \multirow[t]{4}{*}{ VI } & French pear .......... & $\begin{array}{l}\text { Div } \\
\text { DI }\end{array}$ & 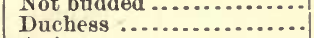 & 58 & $\begin{array}{r}97 \\
3\end{array}$ \\
\hline & & Dir & 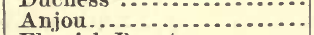 & 59 & $\begin{array}{l}3 \\
2\end{array}$ \\
\hline & & DiII & Flemish Beauty ............. & 58 & $\begin{array}{l}2 \\
2\end{array}$ \\
\hline & & Div & Not bndded .............. & .......... & 251 \\
\hline \multirow[t]{3}{*}{ VII } & French pear .......... & $\mathrm{Ca} 1$ & Flemish Beauty........... & 59 & 51 \\
\hline & & Ca2 & ... . do................... & 64 & 59 \\
\hline & & Cb1 & ..... do....................... & 59 & 55 \\
\hline \multirow{4}{*}{ VIII } & & $\mathrm{Cb} 2$ & 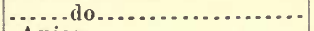 & 62 & 69 \\
\hline & French pear ........... & Ba1 & A njon $\ldots . . . . . . . . .$. & 63 & 62 \\
\hline & & $\mathrm{Ba2}$ & ......do.................... & $\begin{array}{l}61 \\
59\end{array}$ & 63 \\
\hline & & $\begin{array}{l}\text { Bb1 } \\
\text { Bb2 }\end{array}$ & 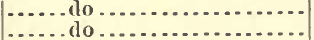 & $\begin{array}{l}59 \\
61\end{array}$ & $\begin{array}{l}63 \\
60\end{array}$ \\
\hline \multirow[t]{15}{*}{$\mathbf{I X}$} & Japan pear............ & $\begin{array}{l}\text { Bb2 } \\
\text { A a1 }\end{array}$ & 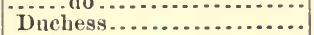 & 15 & $\begin{array}{r}60 \\
9\end{array}$ \\
\hline & & A 22 & . . . do do . . . & 11 & 11 \\
\hline & & $\mathrm{Abl}$ & ..... do do...................... & 14 & 13 \\
\hline & & A 1,2 & 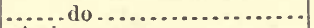 & 12 & 8 \\
\hline & & Ba1 & 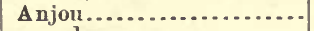 & 14 & 7 \\
\hline & & Ba2 & ...... do & 12 & 12 \\
\hline & & Hb1 & ..... do do.................... & 13 & $\mathbf{9}$ \\
\hline & & Bb2 & 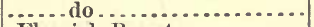 & 14 & 9 \\
\hline & & Ca1 & Flemish Beauty ............ & 16 & 8 \\
\hline & & Ca2 & ...... do ......................... & 17 & 11 \\
\hline & & Cb1 & 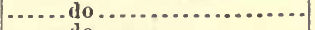 & 13 & 13 \\
\hline & & Clb2 & . . . do . . . . . . . . . . . . . . . & 12 & 13 \\
\hline & & Di & Duchess..................... & 11 & 0 \\
\hline & & DII & A njou $\ldots \ldots \ldots \ldots$ & 13 & 0 \\
\hline & & Dill & Flemish Beauty........... & 14 & 0 \\
\hline \multirow[t]{4}{*}{$\mathbf{X}$} & American pear........ & Div & Not budled ................. & $\cdots \cdots$ & 62 \\
\hline & & WI & 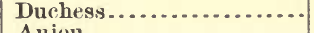 & 29 & 3 \\
\hline & & DII & 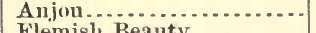 & 28 & $\begin{array}{l}5 \\
2\end{array}$ \\
\hline & & $\begin{array}{l}\text { DiII } \\
\text { Div }\end{array}$ & $\begin{array}{l}\text { Flemish Beauty } \ldots \ldots \ldots \ldots \ldots \\
\text { Not budded } . . . . . . . . . . . . .\end{array}$ & $\begin{array}{c}33 \\
\ldots \ldots\end{array}$ & 202 \\
\hline \multirow[t]{4}{*}{$\mathbf{X I}$} & American pear........ & Ca1 & Flemish Beauty ........... & 71 & 10 \\
\hline & & $\mathrm{Ca2}$ & ....... (lo...................... & 58 & 11 \\
\hline & & Cb1 & .......................... & 57 & 10 \\
\hline & & Cb2 & ......do..................... & 70 & 11 \\
\hline \multirow[t]{4}{*}{ XII } & American pear......... & Bal & Anjou...................... & 56 & 13 \\
\hline & & $\mathrm{Ba} 2$ & 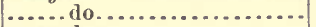 & 58 & 8 \\
\hline & & Bb1 & ......10..................... & 49 & 10 \\
\hline & & Bb2 & 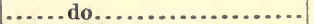 & 63 & 17 \\
\hline \multirow[t]{4}{*}{ XIII } & American pear......... & A a 1 & Duchess ................... & 64 & 21 \\
\hline & & A a 2 & 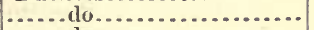 & 38 & 33 \\
\hline & & Ab1 & ......do. ................... & 39 & 16 \\
\hline & & Ab2 & ...... do.................. & 47 & 14 \\
\hline XIV & A merican apple $† . . .$. & & & & \\
\hline$X V$ & American applet ..... & & & & \\
\hline $\mathbf{X V I}$ & French applet........ & & & & \\
\hline XVII & French apple †........ & & & & \\
\hline X VIII & Freneh apple seed- & & & & \\
\hline XIX & French pear seed t.... & & & & \\
\hline $\mathbf{X X}$ & Pcach seedlings t..... & & & & \\
\hline $\mathbf{X X I}$ & French pear ........... & Aa1 & 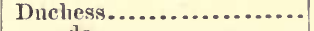 & 53 & 39 \\
\hline & & $\Delta a^{2}$ & ..... do do . .................... & 46 & 37 \\
\hline & & Abl & ...... do & $\begin{array}{l}31 \\
27\end{array}$ & 48 \\
\hline & ${ }^{\circ}$ & Alb2 & ..... nto & 27 & $5 \gamma$ \\
\hline
\end{tabular}

"Shoull have been Flemish Beauty-mistako of budder.

t As no disease appeared in the apple buls data is not valuable. A pple seedlings were not buided; peach showed no disease; none of pear seed germinated.

Soil, stocks, and buds.-The soil upon which the nursery was planted is considered by practical nurserymen as well suited to the growing of plums and cherries but as lacking somewhat in the qualities which go to make np the best soil for pears and apples, being of insufficient depth and a trifle too light. Immediately previons to the experiment the soil had been planted to corn, but what fertilizers had been used, if any, and what crops were grown anterior to that season, I have not been able to ascertain. No fertilizer was applied before putting in the stocks and the 
only treatment the soil received was a dressing in November and December of 1891, of 33 wagon loads of well-rotted barnyard manure from the station manure platforin, evenly distributed between the rows.

The stocks were furnished by various nursery firms as stated in a previous article, ${ }^{*}$ and the different lots were of apparently equal vigor-first grade with the exception of American pear stocks, which owing to the lateness of the season were third grarle. In the planting which was done between the dates of April 27 and May 3, care was taken that each stock was firmly pressed into the soil. Stocks of the same kind from different nursery firms were thoroughly mixed together. In all respects the normal nursery methods were followed out as nearly as possible. The budding was done rn the dates above recorded by two experienced budders employed by the Station. 'Tre scions for cherry, pear, and apple buds were cut from trees growing in the nursery rows t of Selover and Atwood. Plum scions were furnished by Maxwell \& Brois., from their bearing orchard.

Treatment with fungicides. - Only the two well-known fungicides, ammoniacal solution of copper carbonate and Bordeaux mixture were used. The formule used in 1891 were those in common use throughout America. The Bordeaux mixture was diluted in the treatments for 1892 and prepared after the manner first proposed $13 y$ Dr. G. Patrigeon. $\ddagger$

The formulæ are given below:

\section{Ammoniacal solution of copper carbonate, formula used in 1891.}

Five ounces of cupric basic carbonate (copper carbonate) dissolved in ammonia ( 3 to 4 pints of $26^{\circ}$ ) and added to 50 gallons of water. Care was taken that all the carbonate was dissolved in the ammonia, enough being added for the solution.

\section{Ammoniacal solution of copper carbonate, formula used in 1892.}

Identical with the above in strength. The carbonate was wetted with one pint of water, previous to adding the ammonia, to facilitate the solution.

\section{Bordeaux mixture, formula used in 1891.}

Six pounds of cupric sulphate (copper sulphate or bluestone) dissolved in 12 gallons of water. Four pounds of stone lime slaked in a small quantity of water and made up to 3 or 4 gallons of thin milk. The lime was added slowly to the cupric sulphate and the whole made up to 22 gallons.

\section{Bordeaux mixture, formula used in 1892.}

Two pounds cupric sulphate dissolved in 15 gallons of water. Two pounds Rhode Island stone lime slaked in small quantity of water and made up to 5 gallons. The lime was added slowly to the cupric sulphate, testing the mixture frequently during the addition with a fow drops of a concentrated solution of potassinm ferrocyanide (yellow prussiate of potash) and ceasing the addition of the lime when no red color was given to the drops of the ferrocyanide. For convenience this may be called a 60-gallon formula, as it requires that amount of water to contain as much copper sulphate as the standard strength, viz, 6 pounds.

* Bull No. 3, Div. Veg. Path., p. 57.

† A practice much in vogue among unrserymen, but certainly not founded upon a knowledge of the laws governing bud variation. The selection of buds from individual bearing trees of known vigor and productiveness is insisted upon by the best cultivators.

$\ddagger$ Patrigeon, G. Revue Viticole, <Jour. d’ Agric. Pratique, 1890, t. I. 54e année, p. 701. 
The treatments were begun in 1891 about three weeks after planting, when the firstleaves were nearly three-fourt'is grown. The dates upon which the applieatious were made were May 21, June 3, June 24, July 9, July 24, August 8, and August 28. As indicated above in the plan, half' of each section was treated three times. 'Those treated three times were sprayed on the first three dates mentioned.

In 1892 the treatments were begun on May 26, when the leaves had attained full size, and the first appearance of the disease was observed. The dates of treatment are May 26-27, June 15-16, June 23, July 6-7, July 21, and August 5. In order to apply the mixture more thoroughly the spray was passed rapidly over the plants and, the operation repeated after the first spraying had dried. ${ }^{*}$ This method insured as near a complete coating of the fungieide as possible, and it was found that the Bordeaux mixture of this weak strength adhered with remarkable tenacity, being plainly visible twelve weeks after application. $t$ Care was taken to spray the under side of the leaves on the cherry and plum stocks, but pear, quince, and apple stoeks were sprayed from above.

The treatments of 1892 were not continued so late in the season as those of 1891 , and the different sections received respectively five and six sprayings, instead of three and six as in 1891. Those receiving five sprayings were treated on the first five dates mentioned above. The actual amount of the fungicides used will be of little value in estimatiug the quantities that will be necessary in treatments on a large scale, but for the convenience of other experimenters it may be roughly estimated to equal $3 \frac{1}{2}$ to $4 \frac{1}{2}$ gallons of solution per 1,000 one-year-old stocks and proportionately more for budded stoeks. By one-year-old stocks is meant stocks previous to budding.

The spraying was done with a W. \& B. Douglass "Perfection" knapsack sprayer, which proved moderately satisfactory, although a hand-wheel machine would undonbtedly have been better.

\section{DESCRIPTION OF PLATES.}

Plate XXI. French pear stocks, planted in 1891 and treated 7 times with Bordeaux mixture, full strength; left unbudded in the fall and treated 6 times with Bordeanx, one-third strength, in 1892. These could properly be called 3-year-old scellings. Sitnation of stocks, Row VIII, east end.

XXII. French pear stocks, similar to those in Plate xxI, but without treatment either in 1891 or 1892 . Situation of stocks, Row VI, east end. Showing defoliation caused by Entomosporium.

XXIII. French pear stoeks, similar to those in Plate XXI, but treated 7 times in 1891 and 6 times in 1892 with ammoniacal solution. Situation of stocks, Row VIII, near center.

XXIV. Angers quince stocks, planted as euttings in 1891 and treated 7 times with Bordeaux full strength the first season, left unbudded in the fall, and treated 6 times with Bordeanx one-third strength in 1892 . These could properly be called 3 -year-old cuttings. Situation, Row V, near east end.

$X X V$. Angers quince stocks, similar to those in Plate XxIV, bnt withont treatment either in 1891 or 1892. Situation, Row V, east end, one rod east of those in Plate xxiv. Showing defoliation by Entomosporium.

"Suggested first by N. A. Cobb, Dialogue concerning the manner in which a poisonous swray does its work in preventing or cheeking blight. <Agricultural Gazette N. S. Wales, Vol. II, pp. 779-786.

†These double sprayings were made on the first, fourth, fifth, and sixth treatments only.

$\ddagger$ All plates are reproducell from photographs taken 8 feet from the stocks on September 29 and October 11. 
Plate XXVI. Windsor "buds," on Mahaleb. The Mahaleb stocks were treated 7 times in 1891 with Bordeaux mixture and the "buds" were treated 6 times in 1892 with Bordeaux one-third strength. Situation, Row I, near west enà.

XXVII. Windsor "buds," on Mahaleb. Similar to those in Plate xxvi, but untreated both in 1891 and 1892. Situation, Row I, near east end, showing defoliation by Cylindrosporium.

XXVIII. Early Prolific "buds," on Myrobolan. The Myrobolan stocks were treated 7 times in 1891 with Burdeaux and the "buds" were treated 6 times with Bordeaux one-third strength in 1892. Situation, Row III, west end.

XXIX. Early Prolific "buds," on Marianna. Similar to those in Plate XXvir, but untreated both in 1891 and 1892. (The difference of stocks upon which budding was done made no difference as regards the leaf-blight; hence the fact that the "buds" in Plate Xxvin were on Myrobolan stocks and in Plate xxix were on Marianna does not affect the comparison.) Situation, Row IV, east end. 


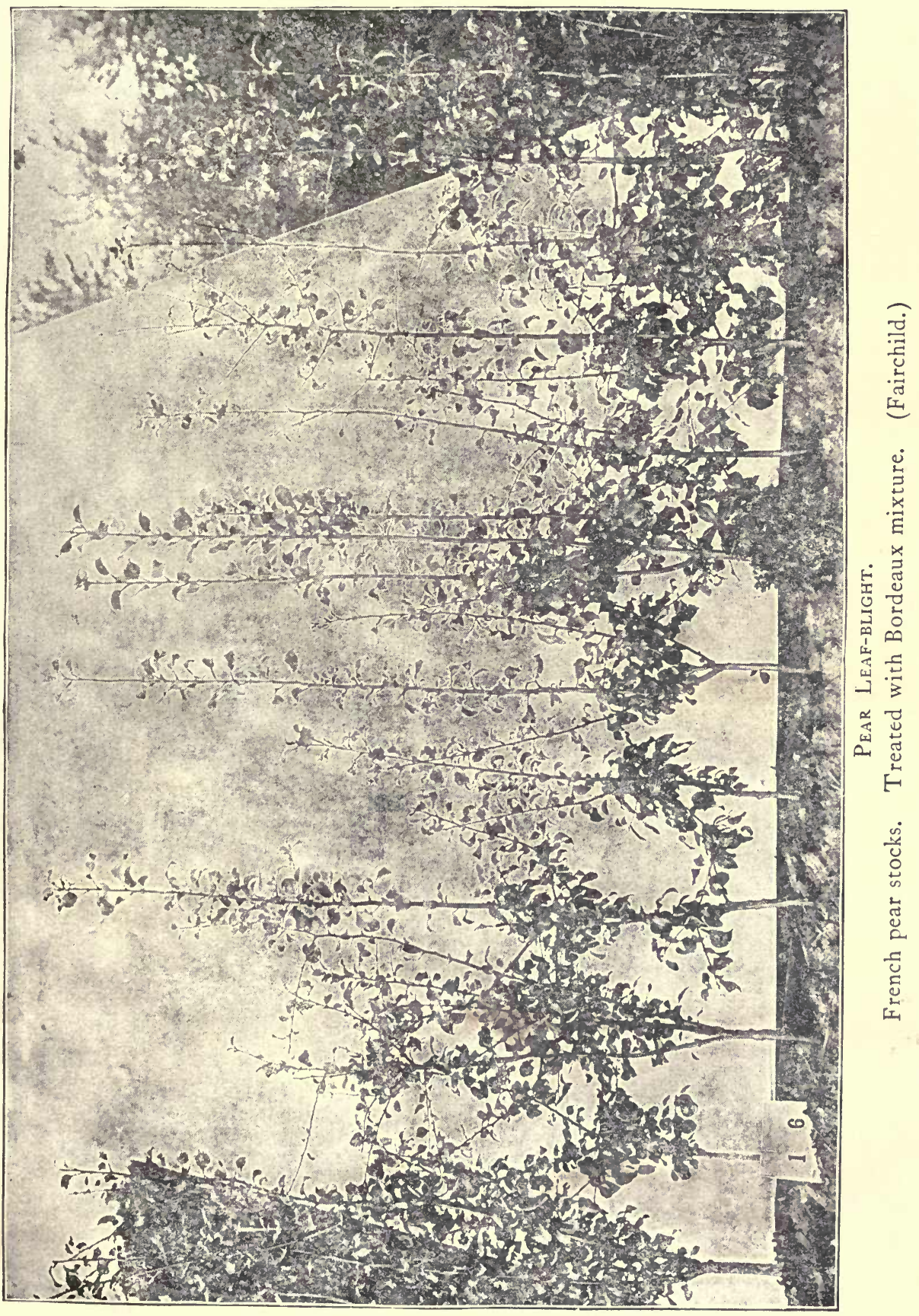



Journal of Mycology, U. S. Department of Agriculture. Vol. ViI, Plate XXil

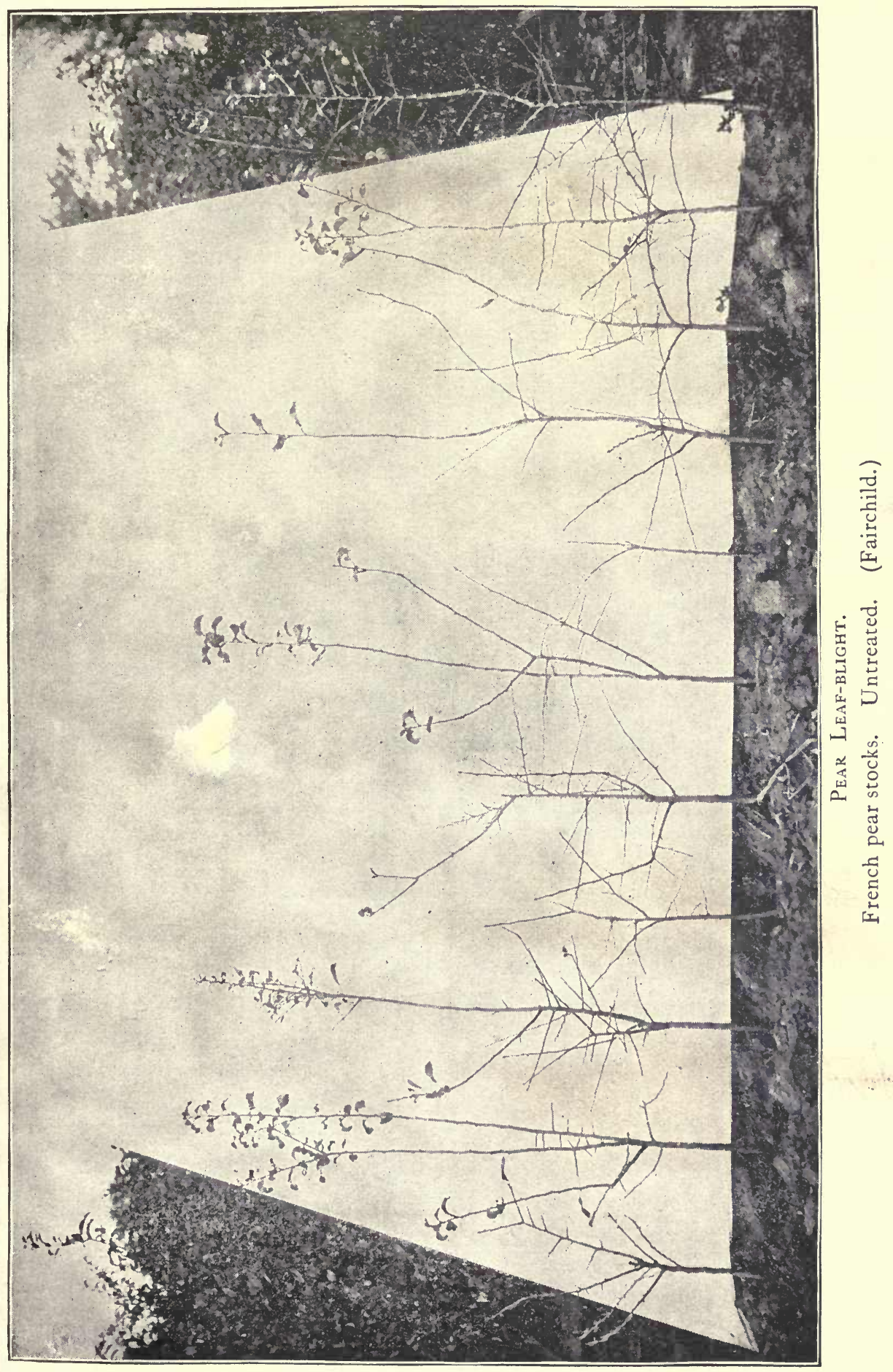




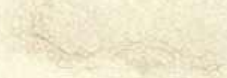

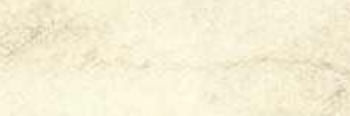




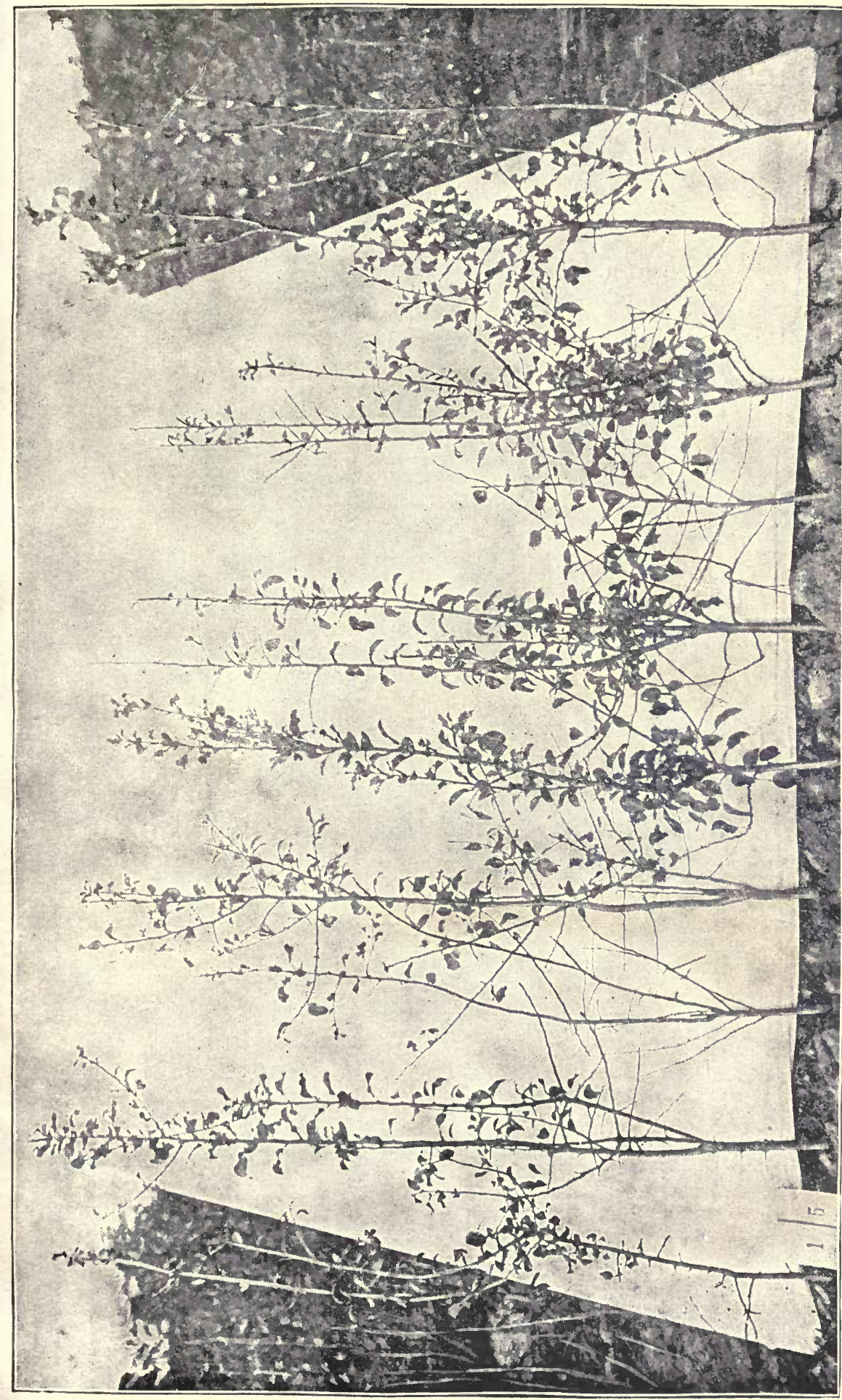



Journal of Mycology, U. S. Department of Agriculture. Vol. Vil, Plate XXiV.

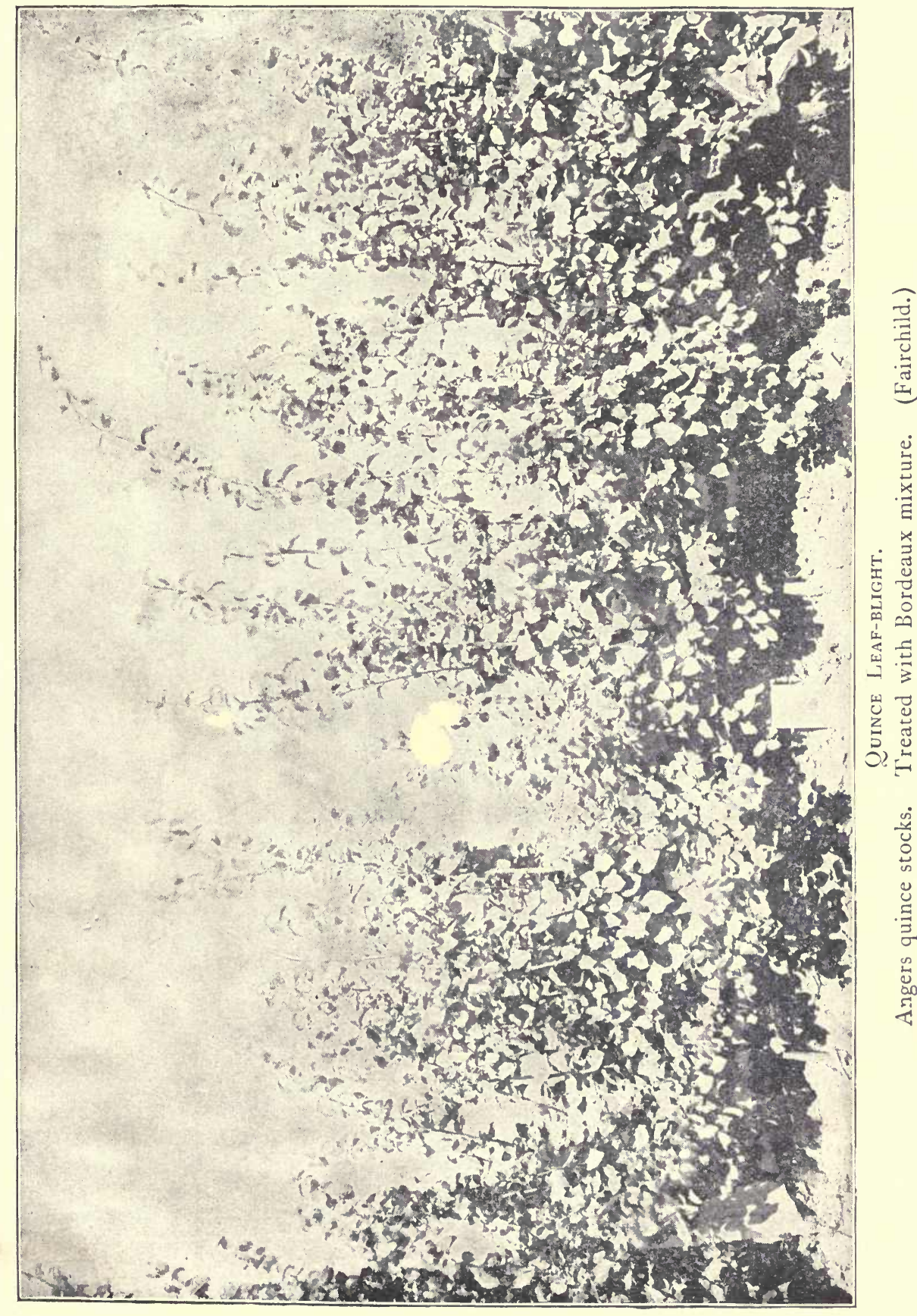




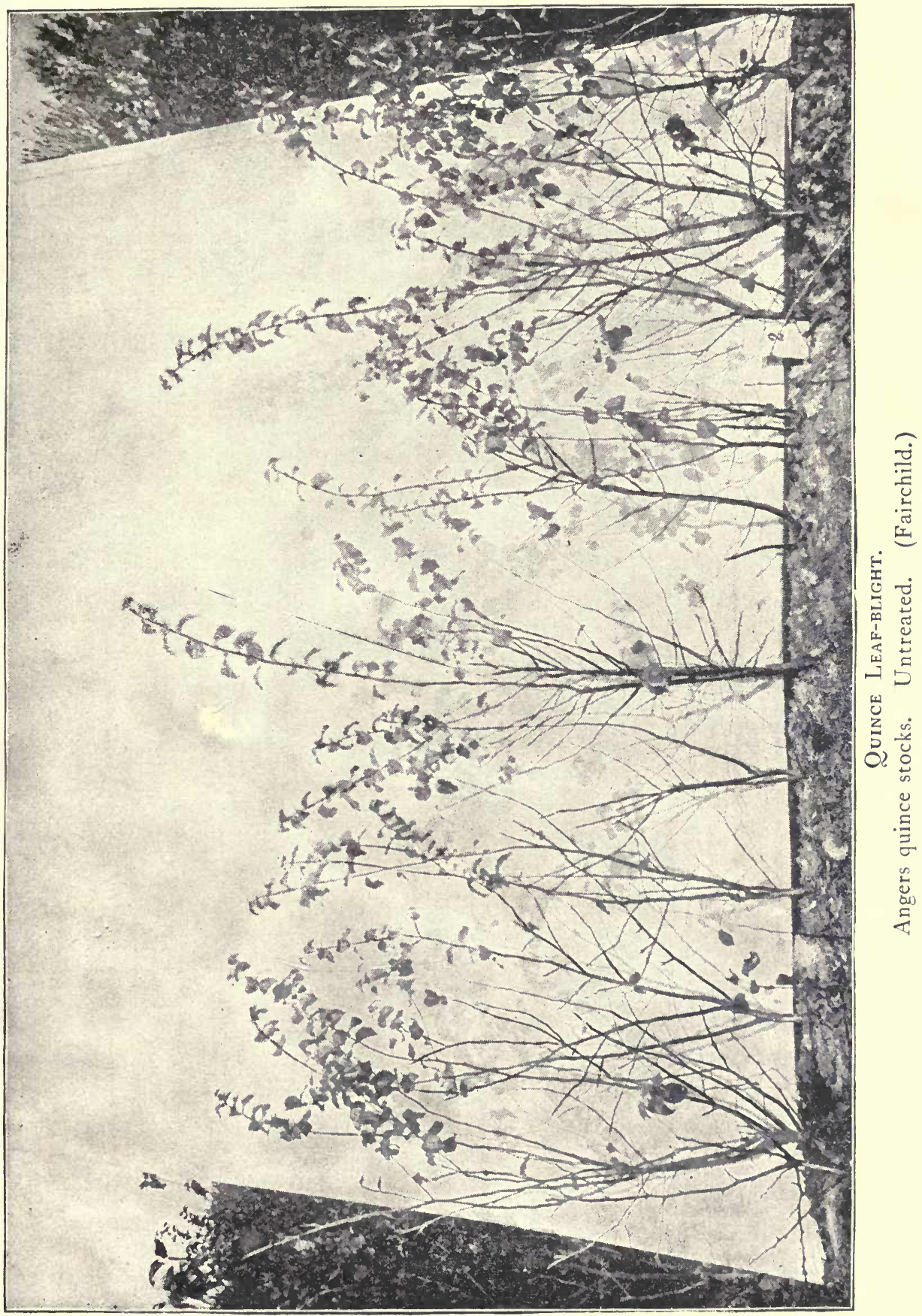



Journal of Mrcology, U. S. Department of Agriculture. Vol. Vit, Plate XXVi.

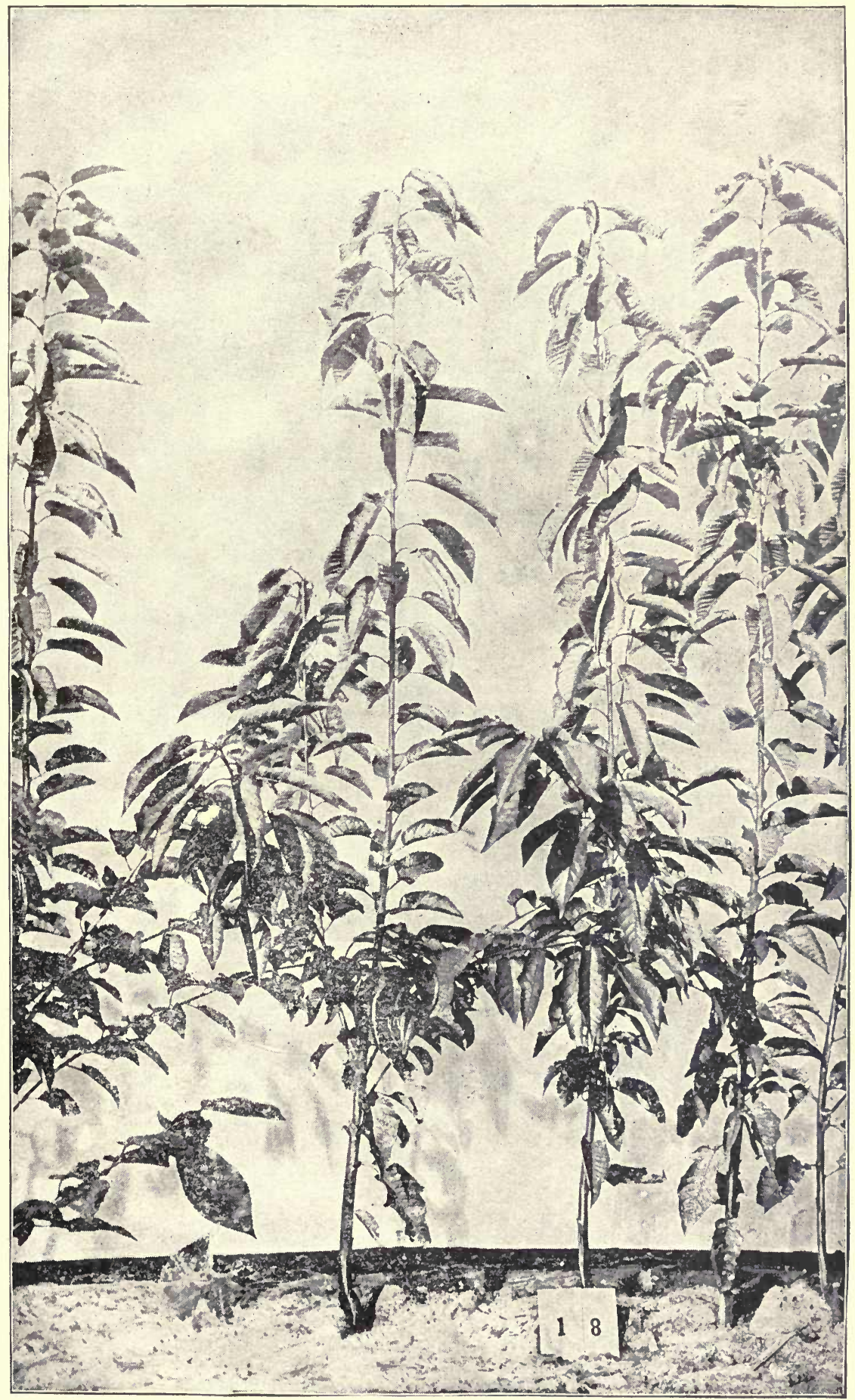

Cherry Leaf-blight.

Windsor buds on Mahaleb stocks. Treated with Bordeaux mixture. (Fairchild.) 

Journal of Mycology, U. S. Department of Agriculture. Vol. Vit, Plate XXVit.

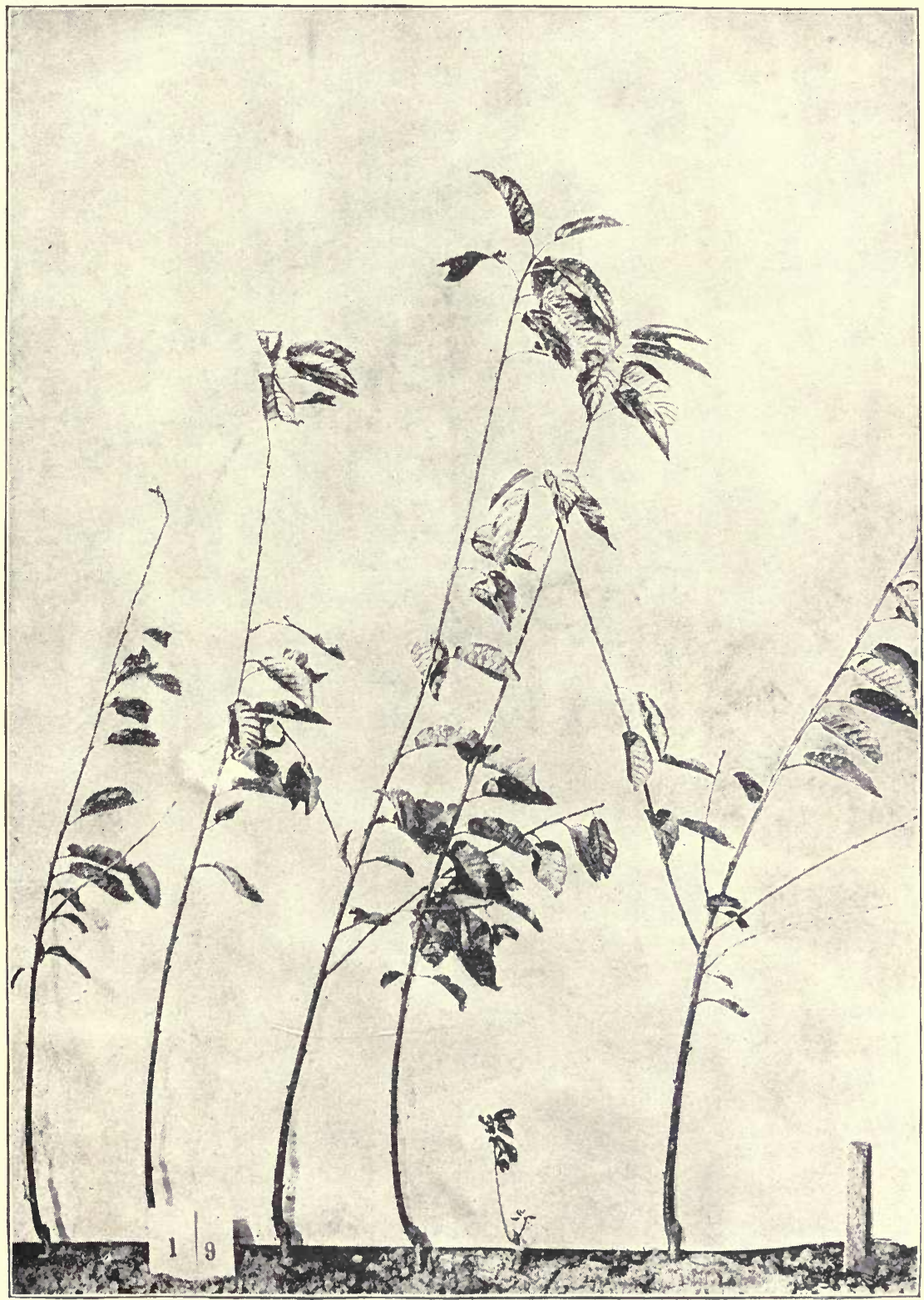

Cherry Leaf-blight.

Windsor buds on Mahaleb stocks. Untreated. (Fairchild.) 
th. an? 
$\therefore \quad \therefore \quad \therefore \quad \therefore \because \because \because \because \because \cdots$

Journal cf Mycology, U. S. Department ó Ágriculture.

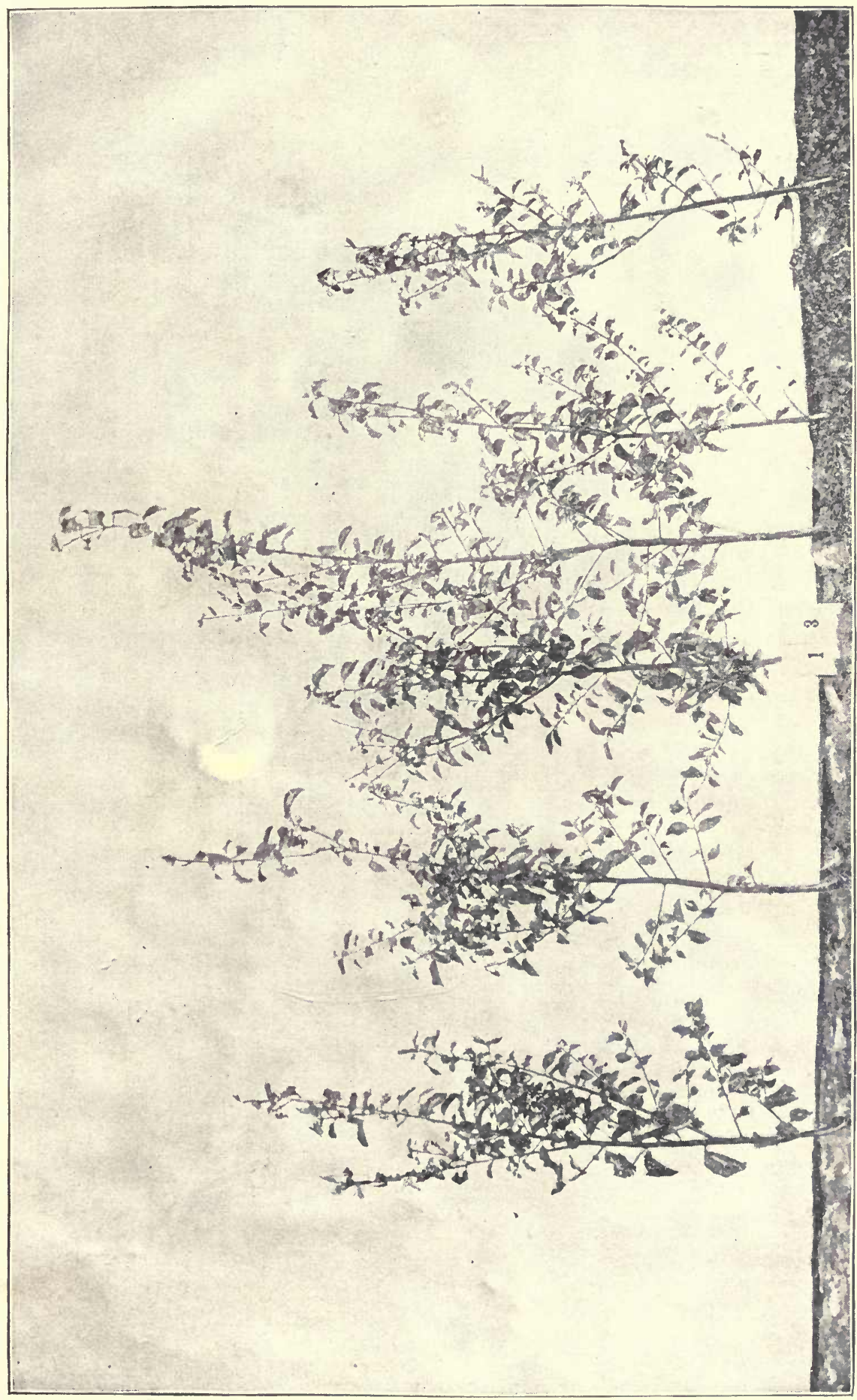


$\because \cdots$

a

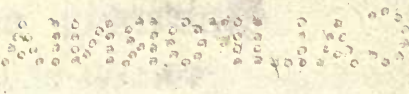

t. 
Journal of Mycology, U. S. Department of Agriculture. Vol. Vil, Plate XXiX.

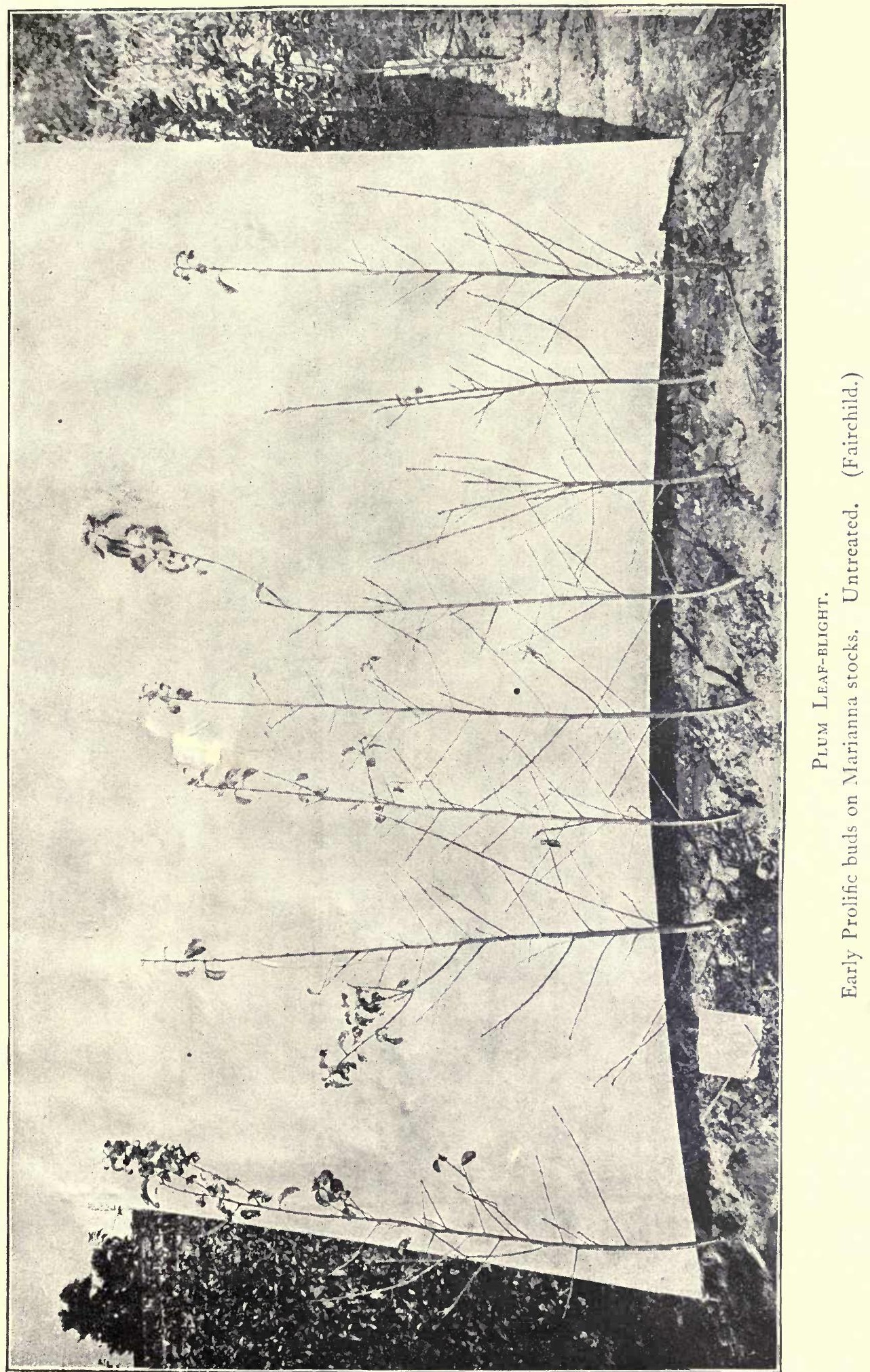





U.C. BERKELEY LIBRARIES

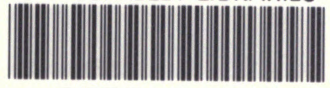

C027471919 
